\title{
Biocompatibility and cytotoxicity in vitro of surface-functionalized drug-loaded spinel ferrite nanoparticles
}

\author{
Sadaf Mushtaq ${ }^{1,2}$, Khuram Shahzad ${ }^{3}$, Tariq Saeed ${ }^{1}$, Anwar Ul-Hamid ${ }^{4}$, \\ Bilal Haider Abbasi ${ }^{2}$, Nafees Ahmad ${ }^{1}$, Waqas Khalid ${ }^{3}$, Muhammad Atif ${ }^{3}$, Zulqurnain Ali ${ }^{3}$ \\ and Rashda Abbasi ${ }^{*}{ }^{*}, \S$
}

\section{Full Research Paper}

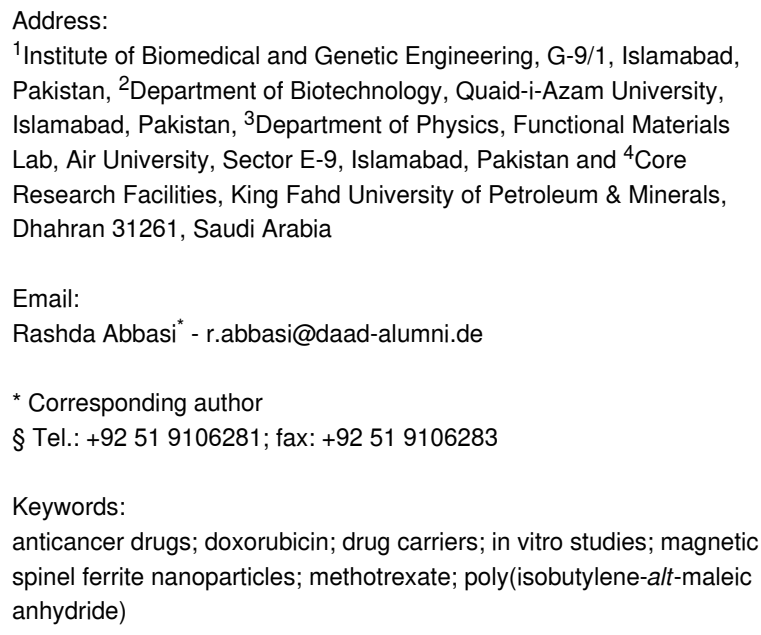

${ }^{1}$ Institute of Biomedical and Genetic Engineering, G-9/1, Islamabad, Pakistan, ${ }^{2}$ Department of Biotechnology, Quaid-i-Azam University, Islamabad, Pakistan, ${ }^{3}$ Department of Physics, Functional Materials Lab, Air University, Sector E-9, Islamabad, Pakistan and ${ }^{4}$ Core Research Facilities, King Fahd University of Petroleum \& Minerals, Dhahran 31261, Saudi Arabia

Email:

Rashda Abbasi* - r.abbasi@daad-alumni.de

* Corresponding author

§ Tel.: +92 51 9106281; fax: +92 519106283

Keywords:

anticancer drugs; doxorubicin; drug carriers; in vitro studies; magnetic spinel ferrite nanoparticles; methotrexate; poly(isobutylene-alt-maleic anhydride)

Beilstein J. Nanotechnol. 2021, 12, 1339-1364. https://doi.org/10.3762/bjnano.12.99

Received: 10 August 2021

Accepted: 15 November 2021

Published: 02 December 2021

Associate Editor: J. Lahann

(C) 2021 Mushtaq et al.; licensee Beilstein-Institut. License and terms: see end of document.

\begin{abstract}
In this study, poly(isobutylene-alt-maleic anhydride) (PMA)-coated spinel ferrite $\left(\mathrm{MFe}_{2} \mathrm{O}_{4}\right.$, where $\mathrm{M}=\mathrm{Fe}, \mathrm{Co}$, $\mathrm{Ni}$, or $\mathrm{Zn}$ ) nanoparticles (NPs) were developed as carriers of the anticancer drugs doxorubicin (DOX) and methotrexate (MTX). Physical characterizations confirmed the formation of pure cubic structures (14-22 nm) with magnetic properties. Drug-loaded NPs exhibited tumor specificity with significantly higher $(p<0.005)$ drug release in an acidic environment ( $\mathrm{pH} 5.5)$. The nanoparticles were highly colloidal (zeta potential $=-35$ to $-26 \mathrm{mV}$ ) in deionized water, phosphate buffer saline (PBS), and sodium borate buffer (SBB). They showed elevated and dose-dependent cytotoxicity in vitro compared to free drug controls. The $\mathrm{IC}_{50}$ values ranged from 0.81 to $3.97 \mu \mathrm{g} / \mathrm{mL}$ for HepG2 and HT144 cells, whereas $\mathrm{IC}_{50}$ values for normal lymphocytes were 10 to 35 times higher $(18.35-43.04 \mu \mathrm{g} / \mathrm{mL})$. Cobalt ferrite (CFO) and zinc ferrite (ZFO) NPs were highly genotoxic $(p<0.05)$ in cancer cell lines. The nanoparticles caused cytotoxicity via oxidative stress, causing DNA damage and activation of p53-mediated cell cycle arrest (significantly elevated expression, $p<0.005$, majorly G1 and G2/M arrest) and apoptosis. Cytotoxicity testing in 3D spheroids showed significant $(p<0.05)$ reduction in spheroid diameter and up to $74 \pm 8.9 \%$ of cell death after two weeks. In addition, they also inhib-

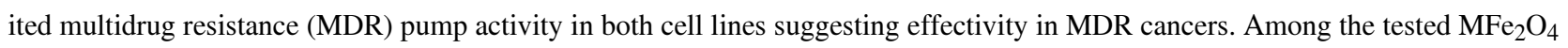
NPs, CFO nanocarriers were the most favorable for targeted cancer therapy due to excellent magnetic, colloidal, cytotoxic, and biocompatible aspects. However, detailed mechanistic, in vivo cytotoxicity, and magnetic-field-assisted studies are required to fully exploit these nanocarriers in therapeutic applications.
\end{abstract}




\section{Introduction}

Cancer is the second leading cause of death and, as such, it is a global health concern [1]. It is caused by uncontrolled cell proliferation, reduced cell death rate, or both [2]. Conventional treatment strategies for cancer, including surgery, radiotherapy, and chemotherapy, lack the ability to selectively target neoplastic tissue, which results in systemic toxicity [3]. For these reasons, the focus of the field was transferred to nanomedicine which enables targeted therapy and reduces side effects of conventional therapeutic agents [4]. Functionalized nanoparticles have the potential to improve the therapeutic performance of drugs by regulating pharmacokinetics and pharmacodynamics [5]. Moreover, water compatibility of nanocarriers provides better chemical stability and bioavailability of the encapsulated drug which allows controlled release. Additional$1 \mathrm{y}$, the attached drug is protected from degradation, which allows an increased circulation time [6]. The targeting of specific tumor tissue is therefore achieved by an increased biodistribution process known as enhanced permeability and retention (EPR) effect [7].

Magnetic nanoparticles (MNPs) have gained significant attention as effective drug delivery systems due to their distinct physiochemical attributes, high surface-to-volume ratio, and the possibility of surface functionalization [8]. Furthermore, magnetic-field-assisted control of the behavior of MNPs makes them suitable candidates for targeted drug delivery, hyperthermia, biosensors, magnetic resonance imaging (MRI), and magnetic separation $[9,10]$. Magnetite $\left(\mathrm{Fe}_{3} \mathrm{O}_{4}\right)$ nanoparticles (NPs), belonging to the spinel ferrite class, are the most extensively studied MNPs for clinical applications and many of them have been approved by the Food and Drug Administration (FDA) agency. Their intended applications include hyperthermia, disease diagnosis, MRI contrasting agents, and improvement of iron deficiencies $[11,12]$. Aside from their useful applications, magnetite NPs have some serious limitations, such as chemical reactivity, rapid oxidation, particle agglomeration, and high surface energy which may affect their biocompatibility and performance [11]. Moreover, they have low magnetization at a smaller size and the presence of iron has been associated with adverse interactions with hemoglobin [13].

Magnetic spinel ferrites nanoparticles (MSFNPs) with a general formula of $\mathrm{MFe}_{2} \mathrm{O}_{4}$ (where $\mathrm{M}=$ divalent cation of $\mathrm{Co}, \mathrm{Ni}, \mathrm{Zn}$, $\mathrm{Mn}$, or $\mathrm{Mg}$ ) are soft magnetic materials with a face-centered cubic structure [14]. Among those, cobalt ferrite NPs have a large magnetocrystalline anisotropy, high saturation magnetization, and coercivity even at room temperature as compared to others [15]. The substitution of metal cations $\mathrm{M}^{+}$for cobalt, nickel, and zinc contributes to diverse magnetic properties, morphology, and size of iron oxide NPs $[13,16]$ along with varied tissue penetration and hemocompatibility which can be useful for biomedical applications [12,17].

Furthermore, in order to be exploited in biomedical applications, NPs need to fulfill certain criteria which include water solubility, excellent colloidal stability, biocompatibility, and high saturation magnetization which enables controlled and nontoxic biological interactions [18]. The hydrophilicity of the nanocarriers is important, as native hydrophobic surfaces of NPs are rapidly opsonized by hydrophobic serum proteins [19]. For this, surface functionalization has a major role [18]. It alters the surface chemistry of NPs, thereby affecting their physiochemical and biological properties $[11,20]$.

In the present work, we synthesized a variety of $\mathrm{MFe}_{2} \mathrm{O}_{4}$ $(\mathrm{M}=\mathrm{Co}, \mathrm{Ni}$, and $\mathrm{Zn}$ ) NPs using the sonochemical technique. Particle agglomeration was prevented by using oleic acid as the surfactant [21]. Phase change of hydrophobic NPs was achieved by the functionalization with an amphiphilic brush copolymer, poly(isobutylene-alt-maleic anhydride) (PMA) implanted with dodecylamine, which provides biocompatibility, colloidal stability, and hydrophilicity [22]. It is composed of hydrophobic side chains and the backbone of hydrophilic groups. The hydrophobic side chains interact with the hydrophobic surfactant (oleic acid) present on the surface of NPs, thereby exposing the hydrophilic end to interact with the aqueous environment and contributing towards a colloidal nanosuspension [23]. The surfaces of the NPs were further functionalized with anticancer drugs, such as doxorubicin (DOX) and methotrexate (MTX) via 1-ethyl-3-(3-dimethylaminopropyl)carbodiimide (EDC) chemistry. The samples were stored at room temperature for further experiments. Our aim was to compare the biocompatibility, colloidal stability, and in vitro cytotoxicity of these nanocarriers for potential anticancer drug delivery systems.

\section{Results and Discussion \\ Physical characterizations}

The X-ray diffraction (XRD) data of all samples was analyzed using Rietveld refinement techniques in the Fullprof Suit program. The data was refined according to their space groups. The Rietveld-refined XRD pattern of the $\mathrm{MFe}_{2} \mathrm{O}_{4}$ nanoparticles (Figure 1a), where triangles indicate experimental data, is shown by the red solid lines which represent the calculated intensities. The difference between the two intensities was indicated by the blue line at the bottom of the graphs and the positions of the Bragg peaks are marked with vertical green lines according to their space groups. All the observed peaks are allowed Bragg's $2 \theta$ positions. The background was refined by using the pseudo-Voigt function and taking atomic fractional positions as fixed parameters during refinement. However, 
a.
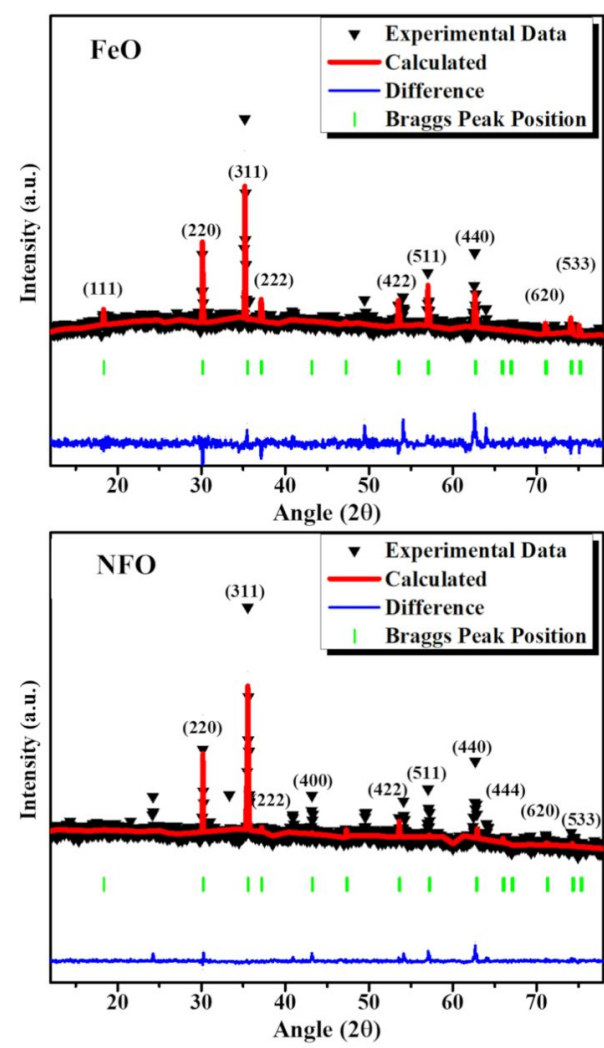

b.
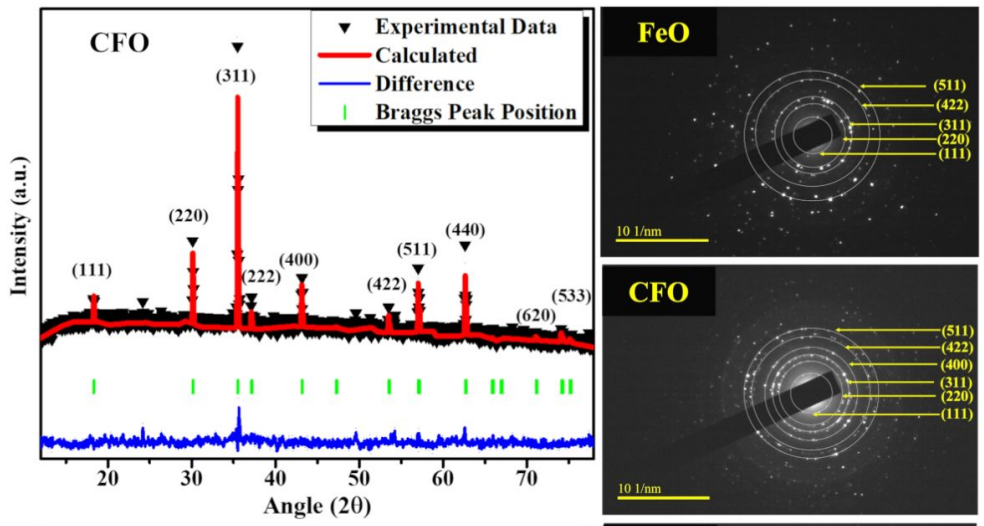

CFO

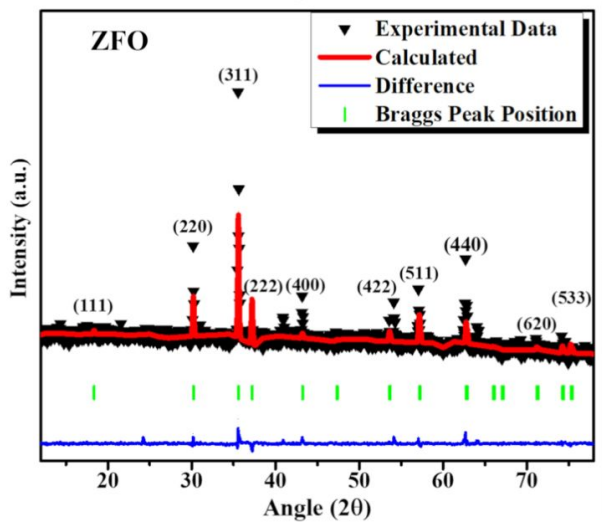

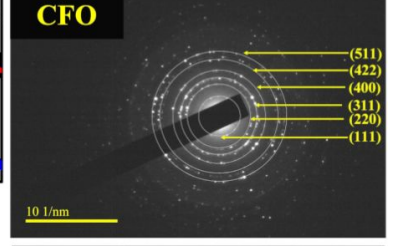

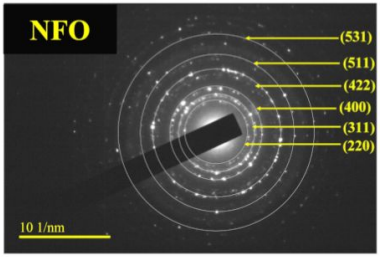

ZFO

Figure 1: (a) Rietveld-refined XRD pattern of $\mathrm{MFe}_{2} \mathrm{O}_{4}(\mathrm{M}=\mathrm{Fe}, \mathrm{Co}, \mathrm{Ni}, \mathrm{Zn}) \mathrm{NPs}$ with SAED images showing different hkl planes. The triangles represent experimental points and the solid red line represents Rietveld-refined data. The bottom line (blue) shows the difference between the experimental and refined data. (b) The marked $2 \theta$ positions are the allowed Bragg peaks.

some factors such as lattice constant, isothermal parameters, scale, and shape factors were considered as free parameters. All the samples show low values of goodness of fit $\left(\chi^{2}\right)$. Several physical parameters (e.g., lattice constant, average crystalline size, density) were calculated as given in Table 1 . The prominent peaks originating from different planes $(111,220,311$, $222,400,422,440,533,620)$, were found in good agreement with standard JCPDS cards (019-0629, 22-1086, 10-0325, and 82-1049 for $\mathrm{M}=\mathrm{Fe}, \mathrm{Co}, \mathrm{Ni}$, and $\mathrm{Zn}$, respectively). A slight peak shift at the (311) plane was observed for cobalt ferrite (CFO), nickel ferrite (NFO), and zinc ferrite (ZFO) as compared to $\mathrm{FeO}$ due to the ionic radii difference of divalent $\mathrm{M}^{+2}$ cations. The peak shift also indicates the incorporation of $\mathrm{M}^{+2}$ cations into the lattice. Further confirmation of the crystalline nature of the composites was obtained by analyzing the selected area electron diffraction (SAED) patterns. The SAED images explain the position of the crystalline system upon diffraction. The results further provide the concentric rings that explains the different hkl planes, as shown in Figure 1b. Furthermore, the formation of the cubic phase of the samples is consistent with the XRD results.
Table 1: Different physical parameters calculated from XRD analysis.

\begin{tabular}{llll} 
Nanostructures & $\begin{array}{l}\text { Crystallite } \\
\text { size }(\mathrm{nm})\end{array}$ & $\begin{array}{l}\text { Lattice } \\
\text { constant }(\AA)\end{array}$ & $\begin{array}{l}\text { Goodness of } \\
\text { fit }\left(\mathrm{X}^{2}\right)\end{array}$ \\
\hline $\mathrm{FeO}$ & 27 & 8.43 & 2.03 \\
$\mathrm{CFO}$ & 23 & 8.39 & 2.11 \\
$\mathrm{NFO}$ & 33 & 8.35 & 2.53 \\
ZFO & 24 & 8.46 & 2.37
\end{tabular}

The formation of spherical NPs was confirmed by transmission electron microscopy (TEM) (Figure 2a). The nanospheres are uniformally distributed throughout the surface of the samples. High-resolution transmission electron microscopy (HR-TEM) images show a crystalline structure with edges of single grains of nanoparticles. The interplanar distance was meaured for each sample with marked lattice fringes of the respective planes. The average particle size was found to be $16-21 \mathrm{~nm}$ for $\mathrm{FeO}$, 14-18 nm for CFO, and 12-16 nm for NFO with $d$ spacing values of $0.47,0.25,0.24$, and $0.20 \mathrm{~nm}$ for $\mathrm{FeO}, \mathrm{CFO}, \mathrm{NFO}$ and 
a.
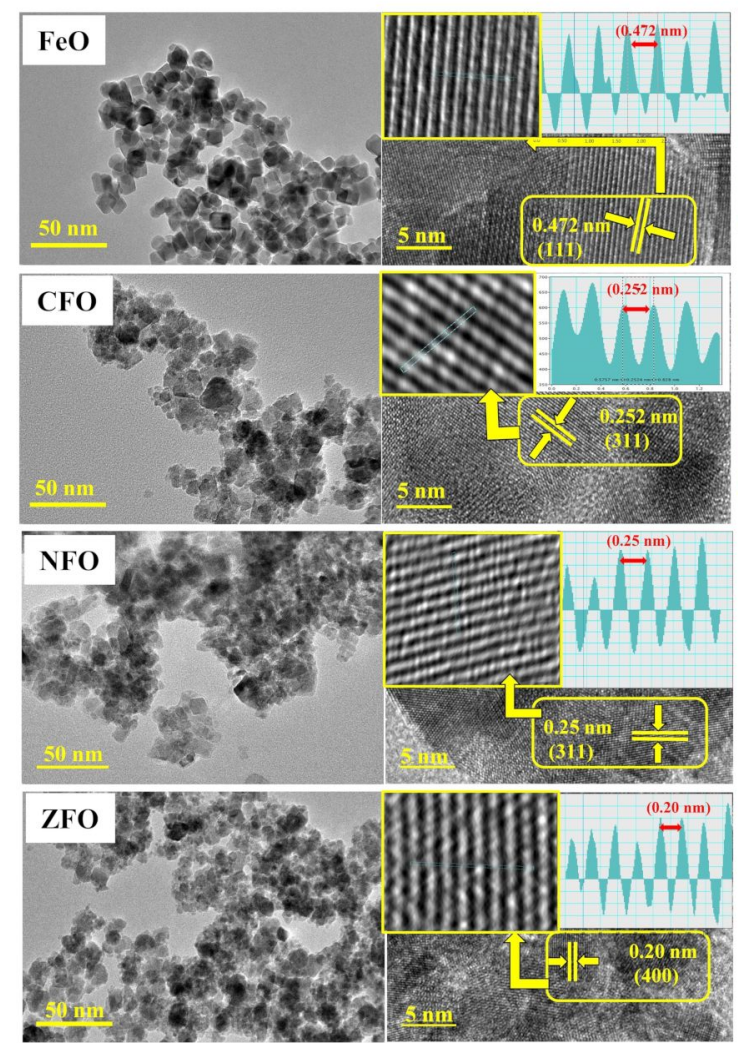

b.
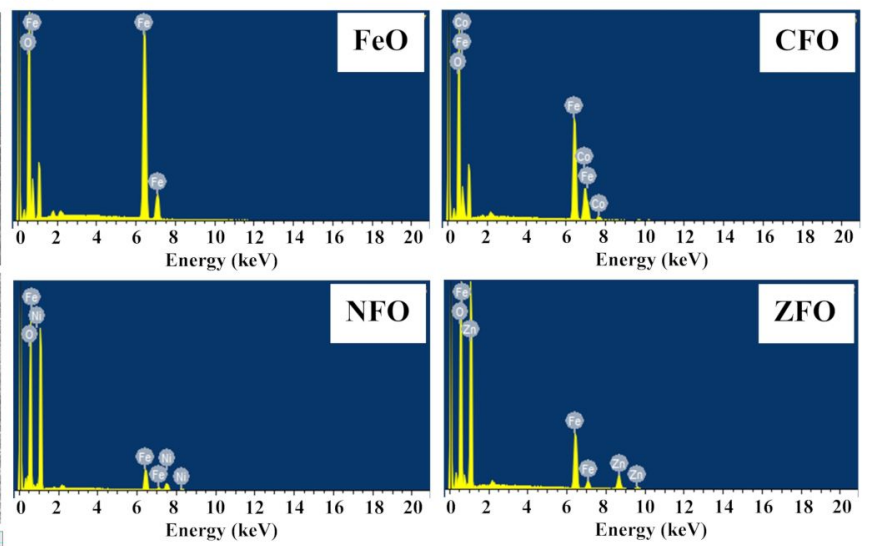

C.

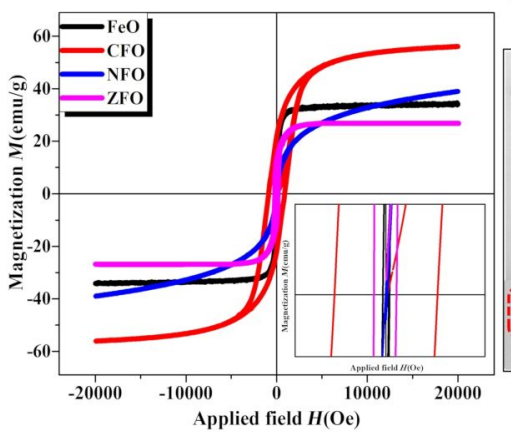

d.

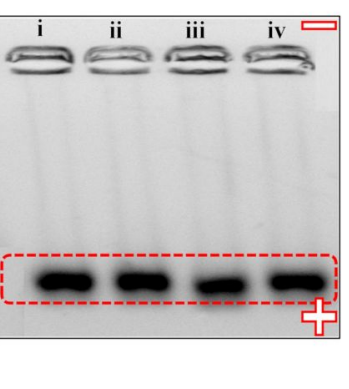

Figure 2: (a) HR-TEM micrographs of $\mathrm{MFe}_{2} \mathrm{O}_{4}(\mathrm{M}=\mathrm{Fe}, \mathrm{Co}, \mathrm{Ni}, \mathrm{Zn}) \mathrm{NPs}$ showing the respective planes. (b) EDS analysis showing major elemental composition in synthesized NPs. (c) Magnetization as a function of the applied field on NPs at room temperature at an applied field of 2.0 T.

(d) Agarose gel electrophoresis image of (i) FeO-PMA, (ii) NFO-PMA, (iii) CFO-PMA, and (iv) ZFO-PMA NPs. The black bands on the gel indicate a uniform size distribution and a negative surface charge on colloidal NPs.

ZFO, respectively, corresponding to (111), (311), (311), and (400), respectively. These planes are well-matched with the interplanar distance of the diffraction pattern standards obtained from their standard JCPDS database.

Weight and atomic $\%$ of $\mathrm{M}=\mathrm{Fe}$ ions in all samples, as studied by energy dispersive spectroscopy (EDS), is given in Table 2 . No extra impurity peaks were present in the spectrum (Figure 2b) due to the use of coprecipitation synthesis methods in which the samples were washed several times to remove any impurity.

The physical property measurement system (PPMS) was used to evaluate magnetic properties of $\mathrm{MFe}_{2} \mathrm{O}_{4}$ NPs. Hysteresis loops were measured at room temperature upon an applied field of $2.0 \mathrm{~T}$. The samples clearly showed ferromagnetic behavior with different saturation magnetization $M_{\mathrm{s}}(\mathrm{emu} / \mathrm{g})$ and coercivity $H_{\mathrm{c}}$ (Oe) values, as shown in Table 3 [24]. From Figure 2c, all sam-

Table 2: EDS analysis showing elemental composition for $\mathrm{MFe}_{2} \mathrm{O}_{4}(\mathrm{M}=\mathrm{Fe}, \mathrm{Co}, \mathrm{Ni}, \mathrm{Zn}) \mathrm{NPs}$.

\begin{tabular}{|c|c|c|c|c|c|c|c|c|c|c|c|}
\hline & $\mathrm{FeO}$ & & CFO & & & NFO & & & ZFO & & \\
\hline & $\mathrm{O}$ & $\mathrm{Fe}$ & $\mathrm{O}$ & $\mathrm{Fe}$ & Co & $\mathrm{O}$ & $\mathrm{Fe}$ & $\mathrm{Ni}$ & 0 & $\mathrm{Fe}$ & $\mathrm{Zn}$ \\
\hline atomic $\%$ & 63.66 & 36.34 & 63.30 & 24.28 & 12.43 & 63.26 & 24.20 & 12.55 & 69.38 & 20.41 & 10.21 \\
\hline weight \% & 33.42 & 66.58 & 36.76 & 46.29 & 16.96 & 37.50 & 48.33 & 14.17 & 40.22 & 42.86 & 16.91 \\
\hline total & 100 & & 100 & & & 100 & & & 100 & & \\
\hline
\end{tabular}


Table 3: Analysis of magnetic parameters for $\mathrm{MFe}_{2} \mathrm{O}_{4}(\mathrm{M}=\mathrm{Fe}, \mathrm{Co}, \mathrm{Ni}, \mathrm{Zn})$ nanoparticles.

\begin{tabular}{llll} 
Samples & Saturation magnetization $M_{\mathrm{S}}(\mathrm{emu} / \mathrm{g})$ & Remanence value $M_{\mathrm{R}}(\mathrm{emu} / \mathrm{g})$ & $\mathrm{Coercivity} H_{\mathrm{C}}(\mathrm{Oe})$ \\
\hline FeO & 34 & 6.2 & 35 \\
$\mathrm{CFO}$ & 56 & 22 & 883 \\
NFO & 39 & 0.32 & 10 \\
ZFO & 25 & 9.21 & 179
\end{tabular}

ples went through saturation at an applied field of $2.0 \mathrm{~T}$, except nickel ferrite. This is may be due to the presence of a strong magnetic anisotropy, which required a higher applied field to induce saturation [25]. Cobalt ferrite has the maximum coercivity $(883 \mathrm{Oe})$ and saturation magnetization values $(56 \mathrm{emu} / \mathrm{g})$ in comparison to other ferrites due to a high anisotropy. Also, during cationic distribution, $\mathrm{Co}^{+2}$ cations incorporate into $\mathrm{Fe}-\mathrm{O}$, whereas the cationic distribution of other divalent metals (e.g., $\mathrm{Ni}^{+2}$ or $\mathrm{Zn}^{+2}$ ) leads to a decrease in magnetic anisotropy $[17,26]$. Moreover, zinc ferrite has a slightly increased coercivity than nickel ferrite and iron oxide due to the formation of a noncollinear ferrimagnetic structure [27]. From Table 3, cobalt ferrite has the best magnetic properties in terms of saturation magnetization and coercivity, followed by iron, nickel, and zinc ferrite. Furthermore, PMA-coated nanoparticles exhibit a small change in saturation magnetization, which is still enough to manipulate NPs using an external magnetic field [28].

The uniform size distribution of $\mathrm{MFe}_{2} \mathrm{O}_{4}(\mathrm{M}=\mathrm{Fe}, \mathrm{Co}, \mathrm{Zn}, \mathrm{Ni})$ NPs was confirmed by agarose gel electrophoresis. All samples moved towards the positive potential due to the negatively charged PMA coating (Figure 2d).
The colloidal stability (i.e., hydrodynamic size, surface charge, and polydispersity index, PDI) of NPs was assessed using dynamic light scattering (DLS). All NPs (PMA-coated, and drug-attached) dispersed in deionized water, sodium borate buffer (SBB) pH 9.0, phosphate buffer saline (PBS) pH 7.4, and DMEM were used for zeta potential measurements. The purpose of using buffers (i.e., SBB, PBS) was to get indirect surface charge information. Deionized water was used to check the influence of electrolytes on the stability of NPs [29], and DMEM was used as a representative of biological assays. All NPs $\left(\mathrm{MFe}_{2} \mathrm{O}_{4}\right.$-PMA, $\mathrm{MFe}_{2} \mathrm{O}_{4}+\mathrm{DOX}$, and $\left.\mathrm{MFe}_{2} \mathrm{O}_{4}+\mathrm{MTX}\right)$ indicated high zeta potential values $(-35$ to $-26 \mathrm{mV})$ in all dispersion media except DMEM ( -17 to $-10 \mathrm{mV}$ ) as shown in Table 4. The reason behind lower zeta potential values is the interaction between NPs and serum proteins present in DMEM [30]. In cell culture media, NPs agglomerate with serum proteins and are therefore recruited in cells via the protein corona effect, which increases the bioavailability of NPs by many folds [31]. PMA-coated samples have a smaller hydrodynamic size (60-93 nm) as compared to drug-loaded samples (74-110 nm), which was further increased (132-210 nm) in DMEM due to the interaction between proteins and samples. Among them, NFO

Table 4: Zeta potential, and average hydrodynamic diameter $\left(D_{\mathrm{z}}\right)$ values of $\mathrm{MFe}_{2} \mathrm{O}_{4}(\mathrm{M}=\mathrm{Fe}, \mathrm{Co}, \mathrm{Zn}, \mathrm{Ni}) \mathrm{NPs}$ by DLS.

\begin{tabular}{|c|c|c|c|c|c|c|c|c|}
\hline \multirow[t]{2}{*}{ Sample } & \multicolumn{4}{|c|}{ Zeta potential $(\mathrm{mV}) \pm \mathrm{SD}$} & \multicolumn{4}{|c|}{ Hydrodynamic size $(\mathrm{nm}) \pm \mathrm{SD}$} \\
\hline & Water & SBB & PBS & DMEM & Water & SBB & PBS & DMEM \\
\hline FeO-PMA & $-33 \pm 1.1$ & $-31 \pm 1.3$ & $-26 \pm 1.9$ & $-17 \pm 2.1$ & $46 \pm 3$ & $66 \pm 4$ & $64 \pm 4$ & $132 \pm 5$ \\
\hline $\mathrm{FeO}+\mathrm{DOX}$ & $-29 \pm 1.7$ & $-25 \pm 1.4$ & $-25 \pm 1.1$ & $-15 \pm 1.8$ & $85 \pm 3$ & $84 \pm 5$ & $110 \pm 2$ & $152 \pm 8$ \\
\hline $\mathrm{FeO}+\mathrm{MTX}$ & $-33 \pm 1.6$ & $-31 \pm 1.9$ & $-27 \pm 1.9$ & $-16 \pm 1.9$ & $91 \pm 3$ & $89 \pm 5$ & $116 \pm 3$ & $157 \pm 6$ \\
\hline CFO-PMA & $-35 \pm 1.8$ & $-27 \pm 1.5$ & $-31 \pm 1.6$ & $-17 \pm 1.3$ & $46 \pm 3$ & $62 \pm 2$ & $70 \pm 5$ & $86 \pm 3$ \\
\hline CFO+DOX & $-32 \pm 1.1$ & $-29 \pm 1.6$ & $-27 \pm 0.9$ & $-15 \pm 1.7$ & $74 \pm 6$ & $83 \pm 5$ & $92 \pm 4$ & $117 \pm 7$ \\
\hline CFO+MTX & $-31 \pm 1.3$ & $-26 \pm 1.2$ & $-26 \pm 1.6$ & $-14 \pm 1.6$ & $64 \pm 2$ & $89 \pm 7$ & $99 \pm 3$ & $145 \pm 5$ \\
\hline NFO-PMA & $-25 \pm 1.1$ & $-23 \pm 1$ & $-27 \pm 0.7$ & $-13 \pm 1.2$ & $84 \pm 6$ & $92 \pm 3$ & $160 \pm 4$ & $151 \pm 8$ \\
\hline $\mathrm{NFO}+\mathrm{DOX}$ & $-24 \pm 1.2$ & $-21 \pm 2.1$ & $-23 \pm 2.6$ & $-10 \pm 1.3$ & $104 \pm 6$ & $108 \pm 3$ & $163 \pm 7$ & $203 \pm 5$ \\
\hline NFO+MTX & $-21 \pm 1.1$ & $-20 \pm 2.3$ & $-24 \pm 1.9$ & $-11 \pm 1.5$ & $110 \pm 6$ & $129 \pm 5$ & $157 \pm 6$ & $210 \pm 3$ \\
\hline ZFO-PMA & $-34 \pm 1.6$ & $-29 \pm 1.9$ & $-29 \pm 1.3$ & $-17 \pm 2.3$ & $54 \pm 5$ & $65 \pm 4$ & $93 \pm 1$ & $135 \pm 6$ \\
\hline ZFO+DOX & $-30 \pm 1.3$ & $-29 \pm 2.2$ & $-28 \pm 1.9$ & $-16 \pm 1.9$ & $74 \pm 3$ & $86 \pm 5$ & $121 \pm 4$ & $153 \pm 6$ \\
\hline ZFO+MTX & $-31 \pm 1.7$ & $-27 \pm 1.5$ & $-27 \pm 1.5$ & $-13 \pm 1.8$ & $79 \pm 4$ & $93 \pm 4$ & $110 \pm 3$ & $157 \pm 8$ \\
\hline
\end{tabular}


has the largest hydrodynamic size (>200 nm) in DMEM, which is not considered suitable for biological applications [30]. All samples have lower PDI values (0.13-0.33) which indicates a uniform distribution of NPs in different dispersion media (Table 5).

\section{$\mathrm{pH}$-dependent drug-loading and drug-release kinetics}

The UV-vis-based confirmation of drug (DOX and MTX) attachment to PMA-coated $\mathrm{MFe}_{2} \mathrm{O}_{4}(\mathrm{M}=\mathrm{Fe}, \mathrm{Co}, \mathrm{Zn}, \mathrm{Ni}) \mathrm{NPs}$ is shown in Figure 3a. Samples were washed and concentrated with centrifugal filters many times to remove unattached drugs. Attached DOX and MTX were indicated at 480 and $372 \mathrm{~nm}$, respectively. The samples NPs-PMA, drug only, and centrifugal filter wastes were also included for comparison. We used $0.5 \mathrm{mM}$ of drugs for the loading on NPs. The encapsulated and loaded drug \% for DOX and MTX are given in Table 6.

For $\mathrm{pH}$-dependent drug-release kinetics, drug-loaded NPs were dispersed in solutions with different $\mathrm{pH}$ values $(1 \times \mathrm{PBS}$;
Table 5: PDI values of $\mathrm{MFe}_{2} \mathrm{O}_{4}(\mathrm{M}=\mathrm{Fe}, \mathrm{Co}, \mathrm{Zn}, \mathrm{Ni}) \mathrm{NPs}$ by DLS.

\begin{tabular}{lllll} 
Sample & Water & PBS & SBB & DMEM \\
\hline FeO-PMA & 0.21 & 0.29 & 0.20 & 0.37 \\
FeO+DOX & 0.27 & 0.25 & 0.21 & 0.45 \\
FeO+MTX & 0.24 & 0.27 & 0.29 & 0.46 \\
CFO-PMA & 0.13 & 0.17 & 0.27 & 0.37 \\
CFO+DOX & 0.19 & 0.21 & 0.29 & 0.49 \\
CFO+MTX & 0.18 & 0.20 & 0.31 & 0.46 \\
NFO-PMA & 0.26 & 0.35 & 0.33 & 0.41 \\
NFO+DOX & 0.33 & 0.41 & 0.41 & 0.51 \\
NFO+MTX & 0.31 & 0.39 & 0.42 & 0.67 \\
ZFO-PMA & 0.18 & 0.15 & 0.20 & 0.39 \\
ZFO+DOX & 0.19 & 0.17 & 0.27 & 0.41 \\
ZFO+MTX & 0.19 & 0.21 & 0.29 & 0.46
\end{tabular}

$\mathrm{pH} 5.5,6.5$, and 7.4) at room temperature and the amount of release (\%) was investigated over a time interval (0-120 min). A strong $\mathrm{pH}$-dependent drug release was observed at a lower

\section{a.}
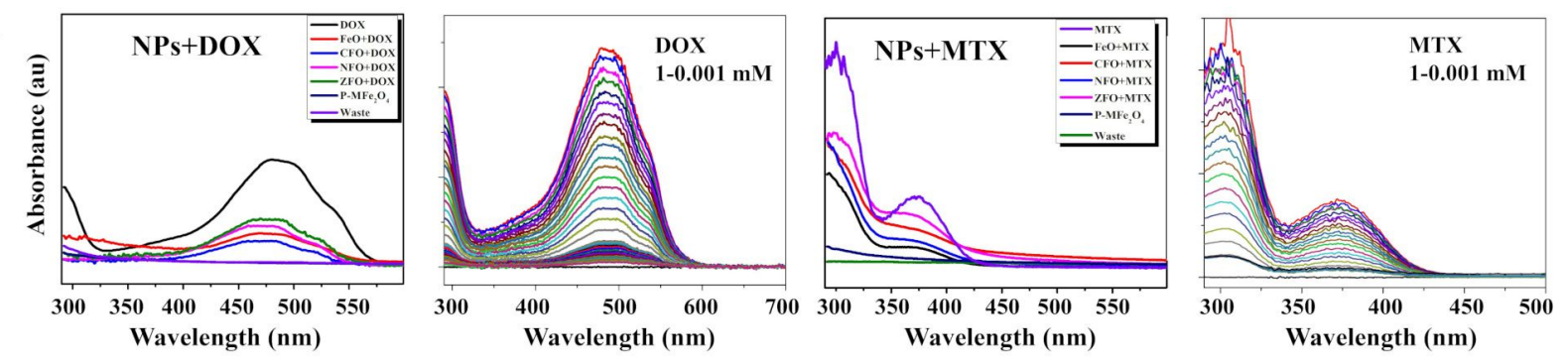

b.
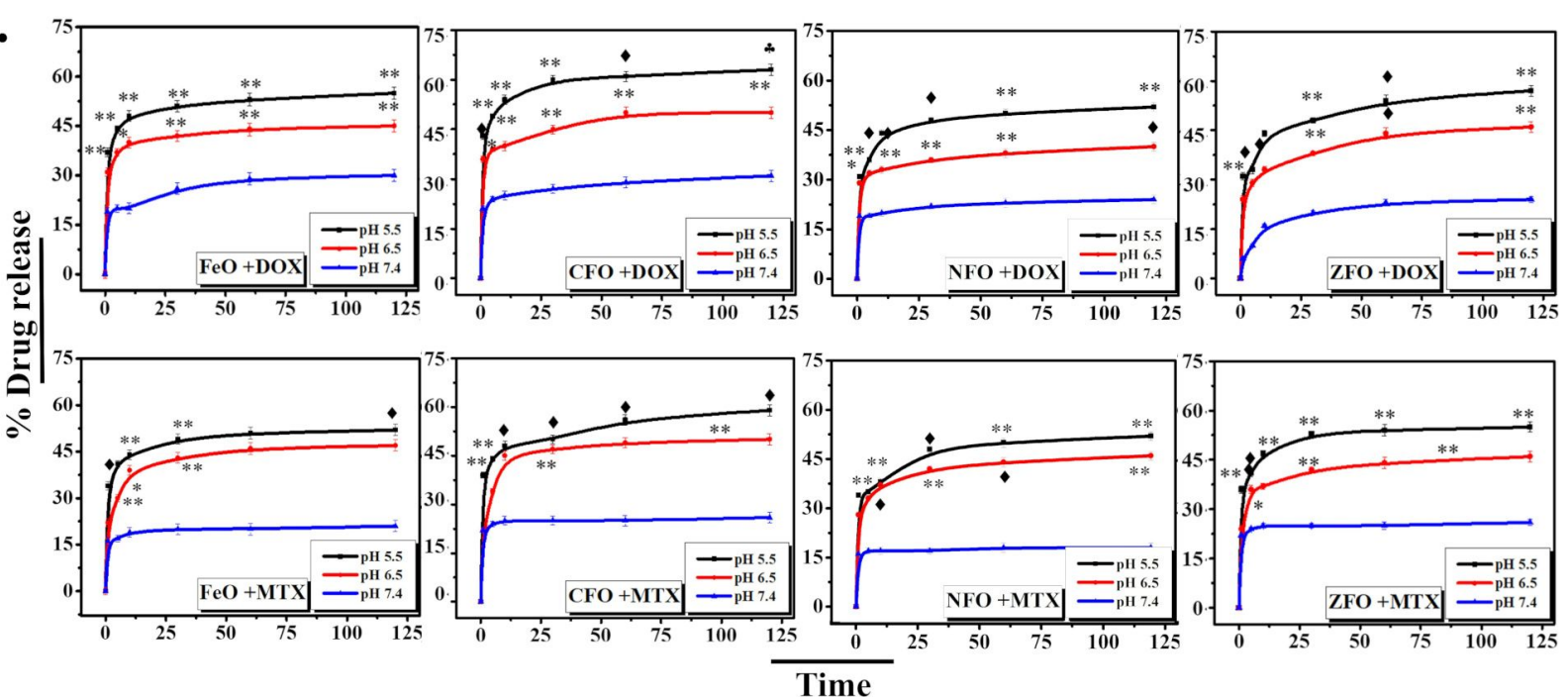

Figure 3: (a) UV-vis absorbance plot of DOX- and $\mathrm{MTX}$-loaded $\mathrm{MFe}_{2} \mathrm{O}_{4}(\mathrm{M}=\mathrm{Fe}, \mathrm{Co}, \mathrm{Zn}, \mathrm{Ni}) \mathrm{NPs}$ indicating drug attachment along with drug titration curves. (b) Drug release kinetics of DOX-and MTX-loaded NPs at pH 5.5, 6.5, and 7.4 at different time intervals ( $0-120$ min). The results indicate mean $\pm \mathrm{SD}$ of three independent experiments. $p<0.05$ (one asterisk), $p<0.005$ (double asterisk), $p<0.01$ (black club symbol), and $p<0.001$ (black diamond symbol), paired two-tailed $t$-test when compared to $\mathrm{pH} 7.4$. 


\begin{tabular}{|c|c|c|c|c|c|c|}
\hline Nanoparticles & EE\% DOX & $\mathrm{EE}(\mu \mathrm{M})$ at $5 \mu \mathrm{g} / \mathrm{mL}$ & EE\% MTX & $\mathrm{EE}(\mu \mathrm{M})$ at $5 \mu \mathrm{g} / \mathrm{mL}$ & LC\% DOX & LC\% MTX \\
\hline $\mathrm{FeO}$ & 79 & 0.08 & 83 & 0.08 & 39 & 41 \\
\hline CFO & 84 & 0.21 & 82 & 0.21 & 42 & 46 \\
\hline NFO & 78 & 0.09 & 80 & 0.10 & 37 & 40 \\
\hline ZFO & 79 & 0.09 & 82 & 0.10 & 43 & 45 \\
\hline
\end{tabular}

$\mathrm{pH}$ value of $5.5(p<0.005)$ in all samples. For drug-loaded NPs, a burst in drug release was observed within the initial 5-10 min (Figure 3b) which indicates that the amide bonds between the drug molecules and NPs were acid labile in nature, resulting in the detachment of the drug from NPs under acidic conditions (pH. 5.5) [32]. The drug release became slower and sustained after that. Acidic conditions change the surface charge density which causes deionization of amide bonds, resulting in drug release [33,34]. From $\mathrm{MFe}_{2} \mathrm{O}_{4}(\mathrm{M}=\mathrm{Fe}, \mathrm{Co}, \mathrm{Zn}, \mathrm{Ni}) \mathrm{NPs}$, CFO had the highest total drug release for DOX and MTX (percent release $=62 \pm 0.99$ and $59 \pm 1.19$, respectively) at a lower $\mathrm{pH}$ value (5.5), followed by $\mathrm{ZFO}, \mathrm{FeO}$, and $\mathrm{NFO}$ as shown in Table 7. The drug release behavior at $\mathrm{pH} 7.4,6.5$, and 5.5 for DOX and MTX shows an increasing curve from higher (7.4) to lower (5.5) $\mathrm{pH}$ values. A small amount of release (20-30\%) for DOX and MTX was observed at $\mathrm{pH} 7.4$, which indicates that the $\mathrm{pH}$-dependent release behavior may contribute to efficient drug delivery at tumor sites where an acidic microenvironment is prevalent [35], with lesser premature drug release in circulation and in normal cells, where the $\mathrm{pH}$ value is maintained at 7.4. Furthermore, once NPs are internalized by tumor cells, the acidic environment in the endosome may also trigger hydrolysis of amide bonds present between the drug and the polymer, thereby rapidly releasing the drug from NPs into the cytosol [36].

\section{Functionalized $\mathrm{MFe}_{2} \mathrm{O}_{4} \mathrm{NPs}$ cause cytotoxicity in vitro}

The sulforhodamine B (SRB) assay was performed using HepG2 and HT144 cells to screen the cytotoxic potential of functionalized $\mathrm{MFe}_{2} \mathrm{O}_{4}(\mathrm{M}=\mathrm{Fe}, \mathrm{Co}, \mathrm{Ni}, \mathrm{Zn}) \mathrm{NPs}$. The cells were exposed to $5 \mu \mathrm{g} / \mathrm{mL}$ of NPs for $24 \mathrm{~h}$. For a better comparison, free drug (DOX and MTX) controls were included, which were equivalent to the total drug amount attached (with a given dose of NPs as mentioned in Table 6). PMA-coated NPs $(5 \mu \mathrm{g} / \mathrm{mL})$ and untreated cultures were also included as controls.

The efficient retention of polymer-functionalized NPs in cancer cells, with the help of the EPR effect and a leaky vasculature system (pore diameter $=100 \mathrm{~nm}-2 \mu \mathrm{m}$ ) [7], reduces their nonspecific biological interactions with plasma proteins, contributing to a higher bioavailability [37]. SRB screening results for HepG2 and HT144 (Figure 4a) cells showed a strong cytotoxic effect $(\%$ viability $<50 \%$ ) upon treatment with drug-loaded NPs compared to nontreated cells (NTC). This cytotoxic effect was prominent when compared to free drug controls, where cell viability was up to $70-80 \%$, indicating higher bioavailability and better internalization of anticancer drugs when loaded on ferrite NPs.

Treated cells also exhibited morphological alterations such as cellular shrinkage and elongation which may affect their ability to metastasize (i.e., to adhere, migrate, and invade) [38]. PMAcoated NPs showed viability up to $80 \%$, indicating excellent biocompatibility of amphiphilic polymers at a lower dose in vitro.

\section{$\mathrm{IC}_{50}$ concentrations of functionalized $\mathrm{MFe}_{2} \mathrm{O}_{4}$ NPs in cancer cells}

To determine $\mathrm{IC}_{50}$ concentrations of drug-loaded NPs and their effect on the metabolic activity of HepG2 and HT144 cells,

Table 7: Total drug (DOX/MTX) release from $\mathrm{MFe}_{2} \mathrm{O}_{4}(\mathrm{M}=\mathrm{Fe}, \mathrm{Co}, \mathrm{Zn}, \mathrm{Ni})$ nanoparticles, at $\mathrm{pH}$ 5.5, 6.5, and 7.4 after 120 min.

\begin{tabular}{|c|c|c|c|c|c|c|}
\hline \multirow[t]{2}{*}{ Nanoparticles } & \multicolumn{3}{|l|}{ DOX } & \multicolumn{3}{|l|}{ MTX } \\
\hline & $\mathrm{pH} 5.5$ & $\mathrm{pH} 6.5$ & $\mathrm{pH} 7.4$ & pH 5.5 & pH 6.5 & $\mathrm{pH} 7.4$ \\
\hline $\mathrm{FeO}$ & $54 \pm 1.05$ & $45 \pm 1.23$ & $30 \pm 0.89$ & $52 \pm 1.15$ & $46 \pm 1.11$ & $23 \pm 0.87$ \\
\hline CFO & $62 \pm 0.99$ & $49 \pm 1.11$ & $29 \pm 1.09$ & $59 \pm 1.19$ & $49 \pm 0.91$ & $26 \pm 1.12$ \\
\hline NFO & $51 \pm 1.02$ & $40 \pm 0.90$ & $25 \pm 0.92$ & $52 \pm 1.08$ & $43 \pm 1.07$ & $19 \pm 0.91$ \\
\hline ZFO & $57 \pm 1.30$ & $46 \pm 1.22$ & $25 \pm 1.23$ & $54 \pm 1.16$ & $45 \pm 0.99$ & $25 \pm 0.92$ \\
\hline
\end{tabular}




\section{a. HepG2}

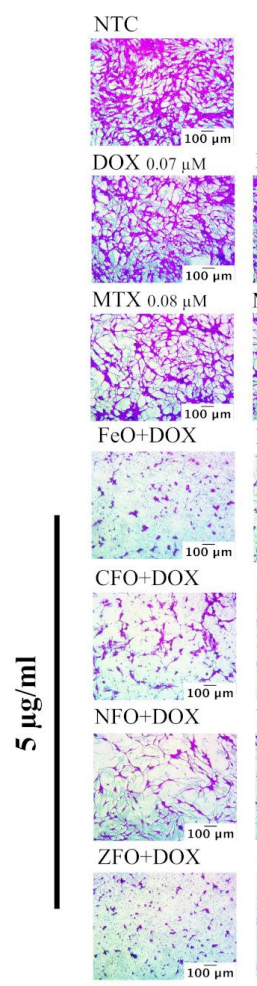

b.

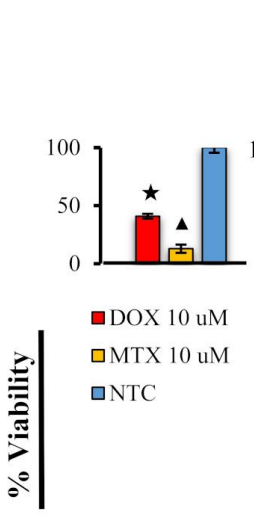

FeO

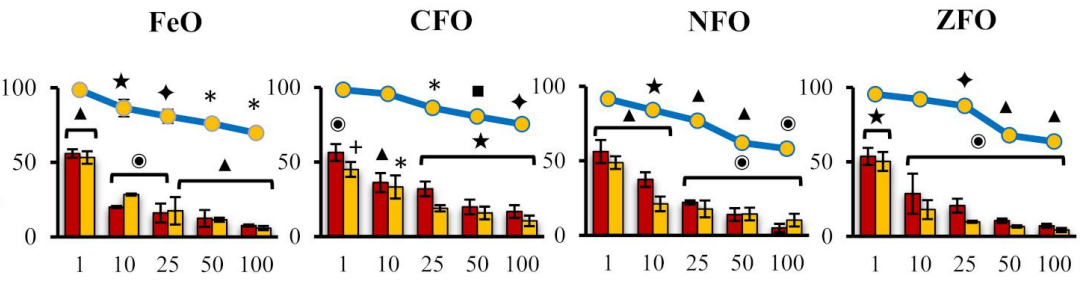

$\begin{array}{llllll}1 & 10 & 25 & 50 & 100\end{array}$

DOX $0.21 \mu \mathrm{M}$

DOX $0.09 \mu \mathrm{M}$

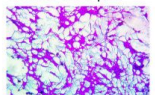

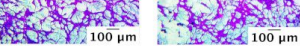

MTX $0.1 \mu \mathrm{M}$

MTX $0.2 \mu \mathrm{M}$

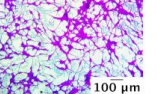

$\mathrm{FeO}+\mathrm{MTX}$
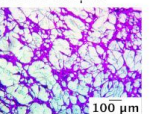

FeO-PMA

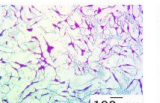

ist?
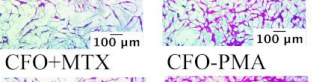

CFO-PMA

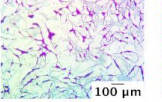

NFO+MTX

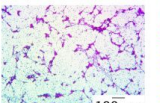

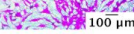

NFO-PMA
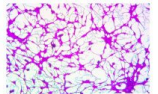

4am 200

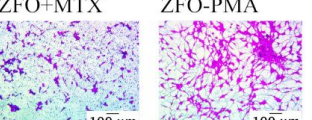

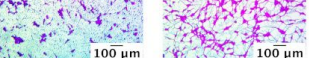

\section{HepG2}

\section{HT144}
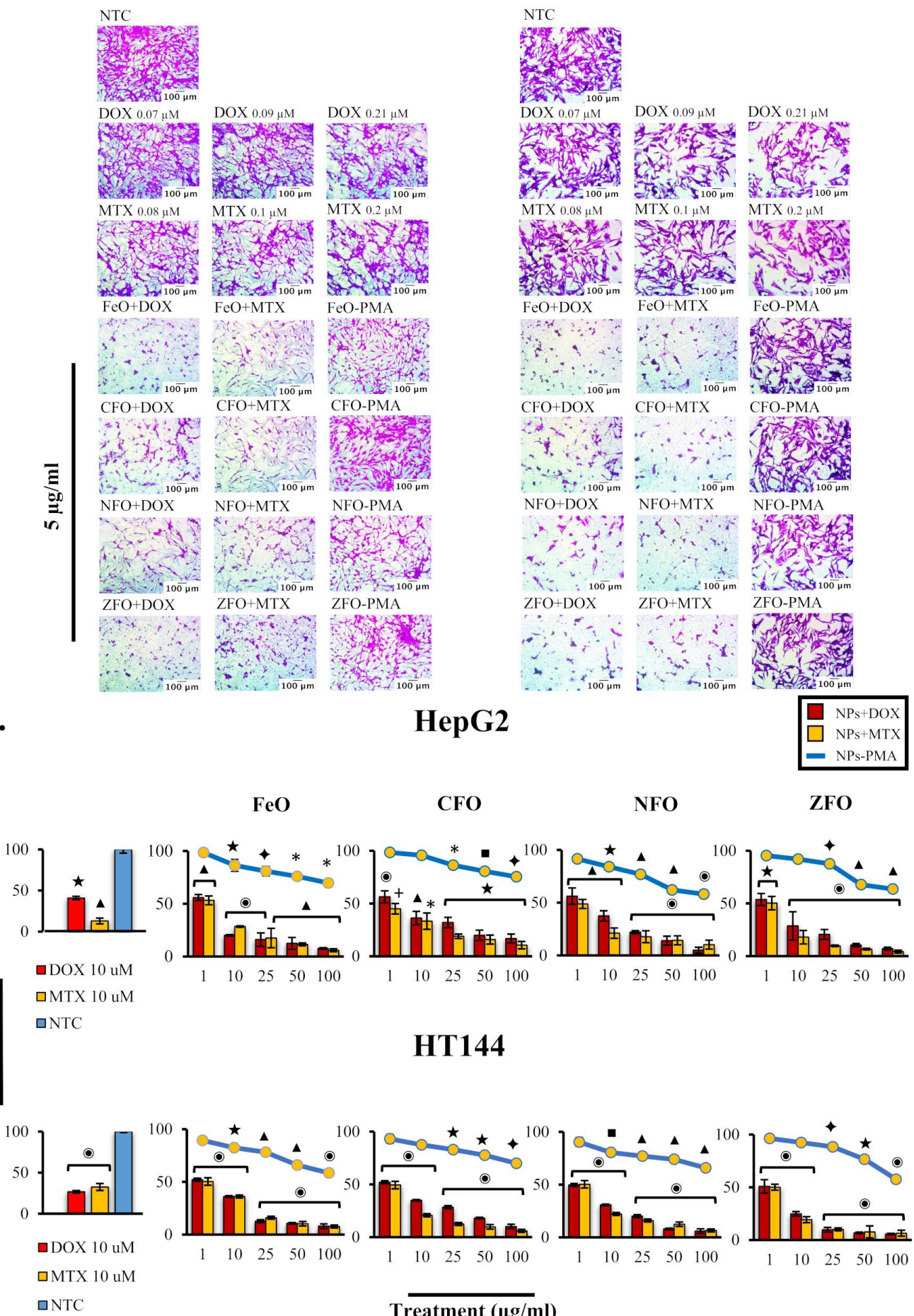

Treatment $(\mu \mathrm{g} / \mathrm{ml})$

Figure 4: (a) Microscopy images of HepG2 and HT144 cells treated with drug-loaded (DOX and MTX) MFe $\mathrm{O}_{4}(\mathrm{M}=\mathrm{Fe}, \mathrm{Co}, \mathrm{Ni}, \mathrm{Zn}) \mathrm{NPs}$ at a $5 \mu \mathrm{gg} / \mathrm{mL}$ dose, for $24 \mathrm{~h}$. For comparison, free drug controls were included, which represented the total drug amount attached to NPs at different dosages (DOX $=0.08,0.21,0.09$, and $0.09 \mu \mathrm{M} ; \mathrm{MTX}=0.08,0.2,0.1$, and $0.1 \mu \mathrm{M}$ respectively). Nontreated controls and PMA-coated samples (NPs-PMA) were also included as controls $(5 \mu \mathrm{g} / \mathrm{mL})$. Magnification $=200 \times$, scale bar $=100 \mu \mathrm{m}$. (b) Dose-dependent cytotoxicity of HepG2 and HT144 cells treated with NPs+drugs and NPs-PMA $(1,10,25,50$, and $100 \mu \mathrm{g} / \mathrm{mL})$ for $24 \mathrm{~h}$. Controls included free DOX and MTX (10 $\mu$ M each) and NTC. Plotted data indicates mean \pm SD of independent triplicates. $p<0.05$ (one asterisk), $p<0.01$ (black square symbol), $p<0.005$ (black diamond symbol), $p<0.001$ (black star symbol), $p<0.0005$ (black triangle symbol), and $p<0.0001$ (circled bullet symbol), paired two-tailed $t$-test when samples were compared to NTC. 
MTT (3-(4,5-dimethylthiazol-2-yl)-2,5-diphenyltetrazolium bromide) assays were performed. Cells were exposed to several concentrations $(1,10,25,50$, and $100 \mu \mathrm{g} / \mathrm{mL})$ of NPs+drugs and NPs-PMA for $24 \mathrm{~h}$. Nontreated samples and free drugs (DOX and MTX, $10 \mu \mathrm{M}$ each) were included as controls. Percentage values of cell viability were plotted for all doses (Figure $4 \mathrm{~b}$ ) and $\mathrm{IC}_{50}$ values were determined (Table 8). In both cell lines, drug-functionalized NPs caused almost $45-50 \%$ reduction in cellular viability at a concentration of $1 \mu \mathrm{g} / \mathrm{mL}$, and the cellular viability decreased even further at higher doses.

In HepG2 cells, cellular viability at a dose of $1 \mu \mathrm{g} / \mathrm{mL}$ ranged from $53.72 \pm 5.65 \%$ to $56.40 \pm 5.46 \%(p<0.001)$ for NPs+DOX and $50.30 \pm 4.94$ to $54.51 \pm 4.24 \%(p<0.05)$ for MTX-loaded NPs. ZFO NPs were the most cytotoxic ones $\left(\mathrm{IC}_{50}=2.34 \mu \mathrm{g} / \mathrm{mL}\right.$ and $1.08 \mu \mathrm{g} / \mathrm{mL}$ for $\mathrm{ZFO}+\mathrm{DOX}$ and ZFO+MTX, respectively). In HT144 cells, cellular viability values of $49.70 \pm 1.41$ to $52.10 \pm 1.45 \%$ and $49.40 \pm 3.53$ to $50.29 \pm 3.21(p<0.0001)$ were observed upon treatments with NPs+DOX and NPs+MTX $(1 \mu \mathrm{g} / \mathrm{mL})$, respectively. NFO+DOX $\left(\mathrm{IC}_{50}=0.86 \mu \mathrm{g} / \mathrm{mL}\right)$ and CFO+MTX $\left(\mathrm{IC}_{50}=0.81 \mu \mathrm{g} / \mathrm{mL}\right)$ were the most cytotoxic ones.

PMA-coated NPs used as a control in this study were comparatively nontoxic to the cells with a relative percentage viability ranging from $98.53 \pm 0.76 \%$ to $84.11 \pm 1.29 \%$ against HepG2 using different NPs-PMA at various concentrations. Similarly, for HT144 the percentage viability ranged from $96.35 \pm 0.50$ to $80.4 \pm 2.48 \%$, indicating biocompatibility and higher tolerance of the drug-free particles.

The drug-loaded NPs showed 1.6- to 12-fold stronger effects when compared to the NPs-PMA at the same doses.

\section{Functionalized $\mathrm{MFe}_{2} \mathrm{O}_{4} \mathrm{NPs}$ cause apoptosis in a dose-dependent manner}

Fractions of live, dead, and apoptotic cells (HepG2 and HT144) were quantitatively determined by fluorescence microscopy using acridine orange and propidium iodide (AOPI) staining. Cells were treated with drug-loaded NPs for $3 \mathrm{~h}$ at concentration values of 5 and $10 \mu \mathrm{g} / \mathrm{mL}$. NTC, NPs-PMA $(10 \mu \mathrm{g} / \mathrm{mL})$ and free drugs (DOX and MTX, $5 \mu \mathrm{M}$ each) were included as controls. After treatment and staining with AOPI, cells were observed under a fluorescence microscope where viable cells appeared green, apoptotic cells appeared orange/yellow, and necrotic cells appeared red in color (Figure 5a). Percentage fractions of live, necrotic, and apoptotic cells were calculated in each replicate and compared to NTC (Figure 5b). Spinel ferrite NPs have been reported to cause cytotoxicity in cancer cells, mediated via ROS production, increased transcription of p53 and apoptotic genes (caspase 3 and 9, Bax), and downregulation of the antiapoptotic $\mathrm{Bcl}-2$ gene, leading to programmed cell death [39]. However, the chemical composition of NPs plays an important role in determining cytotoxic behavior. For example, NPs with cores made up with toxic metals (e.g., $\mathrm{Cd}$ and $\mathrm{Ag}$ ) cause cytotoxicity. Conversely, metals such as $\mathrm{Fe}$ and $\mathrm{Zn}$ are biocompatible and cause toxicity at higher doses or by leakage of the metal ions from the core surface, causing oxidative stress. This phenomenon can be controlled by coating the NPs with polymeric shells, which enhances their biocompatibility and stability [40].

All drug-loaded samples exhibited a dose-dependent response. Among DOX-loaded NPs, ZFO+DOX was the most cytotoxic in HepG2 cells, with an apoptotic cell fraction of $43.12 \pm 2.35 \%$ at a $5 \mu \mathrm{g} / \mathrm{mL}$ dose $(p<0.01)$. Conversely, FeO+DOX,

Table 8: $\mathrm{IC}_{50}$ values $(\mu \mathrm{g} / \mathrm{mL})$ of drug-loaded $\mathrm{MFe}_{2} \mathrm{O}_{4}$ nanoparticles with attached drugs $(\mu \mathrm{M})$.

\begin{tabular}{|c|c|c|c|c|c|c|}
\hline \multirow[t]{2}{*}{ Sample } & \multicolumn{2}{|l|}{ HepG2 } & \multicolumn{2}{|l|}{ HT144 } & \multicolumn{2}{|l|}{ Lymphocytes } \\
\hline & $\mathrm{IC}_{50}(\mu \mathrm{g} / \mathrm{mL})$ & Attached drug $(\mu \mathrm{M})$ & $\mathrm{IC}_{50}(\mu \mathrm{g} / \mathrm{mL})$ & Attached drug $(\mu \mathrm{M})$ & $\mathrm{IC}_{50}(\mu \mathrm{g} / \mathrm{mL})$ & Attached drug $(\mu \mathrm{M})$ \\
\hline $\mathrm{FeO}+\mathrm{DOX}$ & 2.48 & 0.04 & 2.18 & 0.03 & 22.68 & 0.36 \\
\hline CFO+DOX & 3.81 & 0.16 & 2.08 & 0.09 & 35.96 & 1.51 \\
\hline $\mathrm{NFO}+\mathrm{DOX}$ & 3.97 & 0.07 & 0.86 & 0.01 & 18.35 & 0.32 \\
\hline ZFO+DOX & 2.34 & 0.07 & 1.30 & 0.02 & 24.54 & 0.73 \\
\hline $\mathrm{FeO}+\mathrm{MTX}$ & 2.18 & 0.03 & 1.18 & 0.01 & 41.65 & 0.57 \\
\hline CFO+MTX & 1.23 & 0.05 & 0.81 & 0.03 & 43.04 & 1.75 \\
\hline NFO+MTX & 2.31 & 0.02 & 1.09 & 0.02 & 21.04 & 0.18 \\
\hline ZFO+MTX & 1.08 & 0.02 & 1.02 & 0.02 & 38.71 & 0.71 \\
\hline
\end{tabular}


a.

HepG2

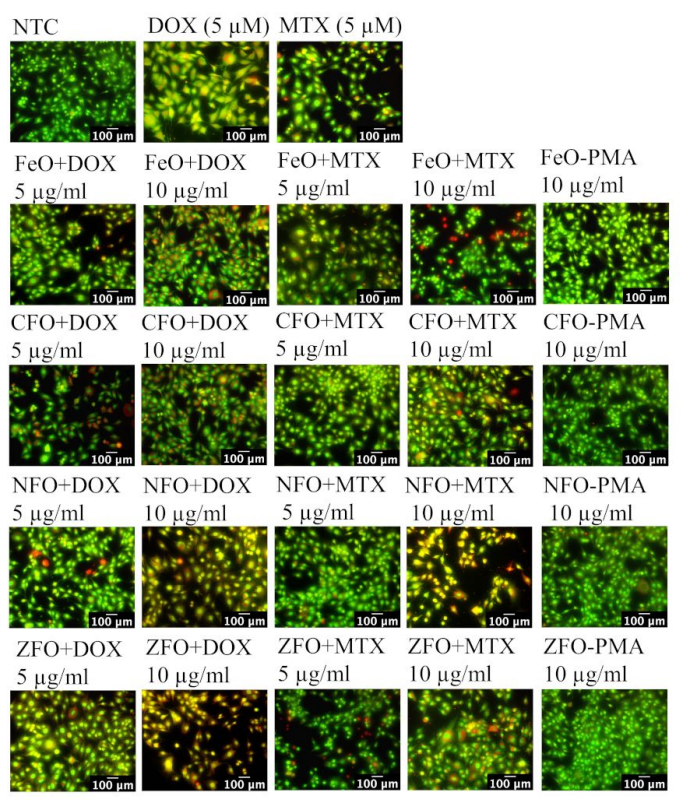

HT144

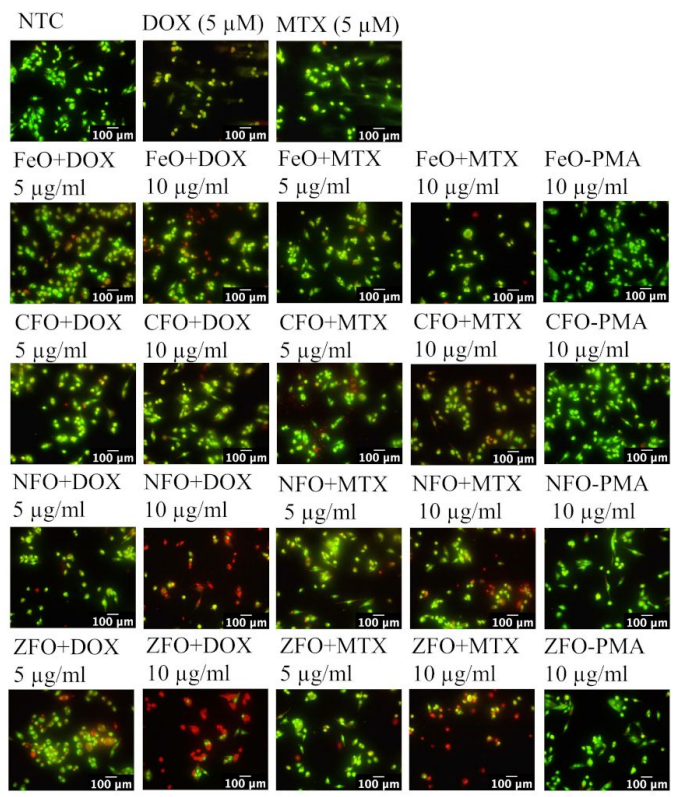

b.

HepG2

Viable cells $\square$ Apoptotic cells $\square$ Necrotic cells

Controls

NPs+DOX

NPs+MTX
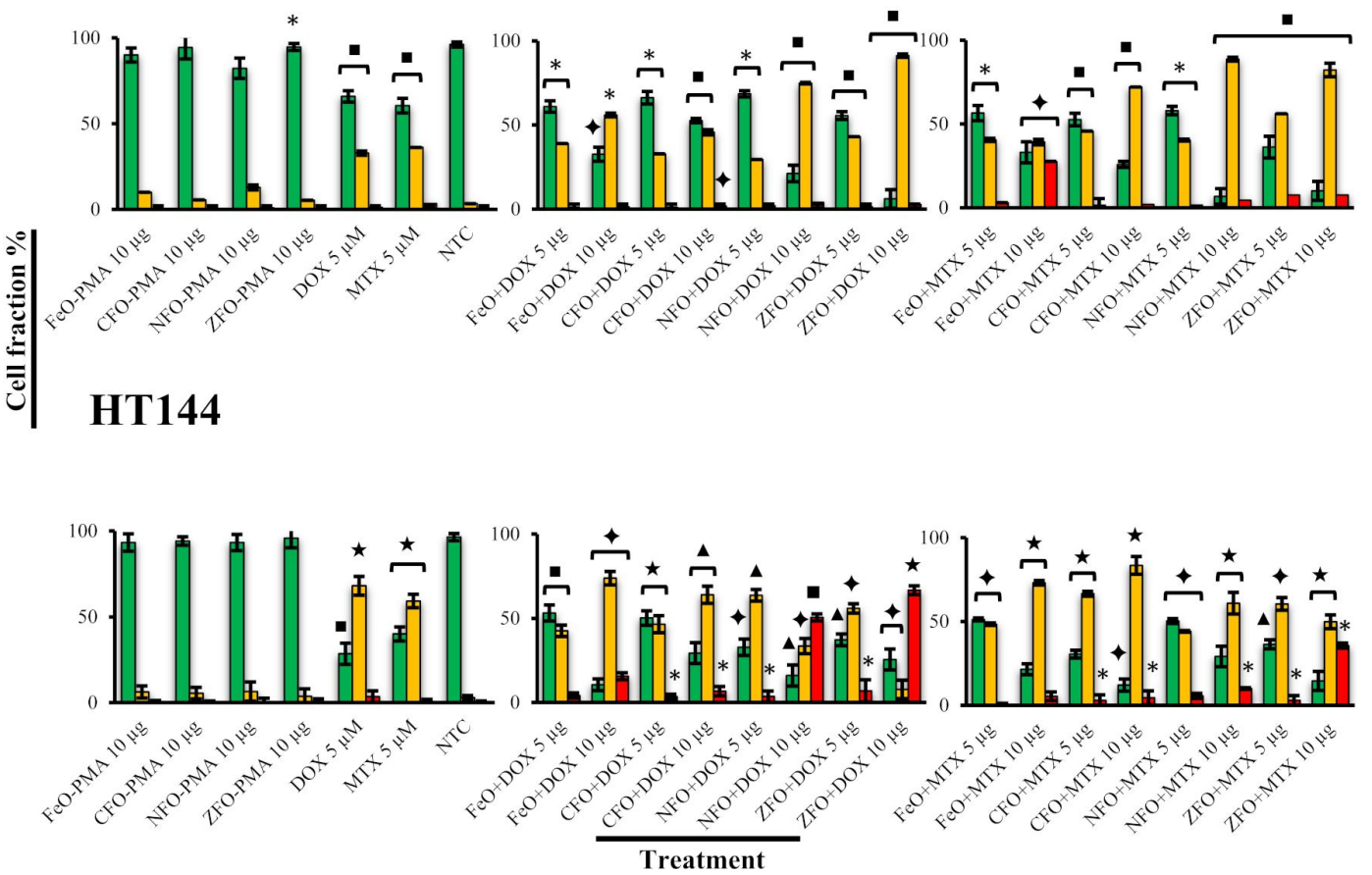

Figure 5: (a) Fluorescence microscopy images of $\mathrm{HepG} 2$ and $\mathrm{HT} 144$ cells upon treatment with drug-loaded (DOX and $\mathrm{MTX}) \mathrm{MFe}_{2} \mathrm{O}_{4}(\mathrm{M}=\mathrm{Fe}, \mathrm{Co}, \mathrm{Ni}$, $\mathrm{Zn}$ ) NPs at 5 and $10 \mu \mathrm{g} / \mathrm{mL}$ for $3 \mathrm{~h}$. Controls included free drugs (DOX and MTX, $5 \mu \mathrm{M}$ ), NPs-PMA (10 $\mu \mathrm{g} / \mathrm{mL}$ ), and NTC. Live cells are shown in green, necrotic cells are shown in red, and apoptotic cells are shown in yellow to orange range due to AOPI staining. Magnification $=200 x$, scale bar $=100 \mu \mathrm{m}$. (b) Quantitative analysis of the percentage of viable, apoptotic, and necrotic cells (mean \pm SD of experimental triplicates) in treated HepG2 and HT144 cells in comparison to controls. $p<0.05$ (one asterisk), $p<0.01$ (black square symbol), $p<0.005$ (black diamond symbol), $p<0.001$ (black star symbol), and $p<0.0005$ (black triangle symbol), two-tailed $t$-test when samples were compared to NTC. 
CFO+DOX, and NFO+DOX showed $39 \pm 3.39,32.83 \pm 3.81$, and $29.5 \pm 1.93 \%$ of apoptotic cells $(p<0.05$ ), respectively. The percentage of apoptotic cells increased by 1.4 - to 2.5 -fold $(p<0.05)$ at higher doses, with maximum apoptosis observed in ZFO+DOX (91.24 $\pm 5.43 \%)$. In case of MTX-loaded samples, approximately $40.51 \pm 3.70$ to $56.26 \pm 5.34 \%$ of apoptotic cells $(p<0.05)$ were observed at a $5 \mu \mathrm{g} / \mathrm{mL}$ dose, with ZFO+MTX being the most cytotoxic. The apoptotic fraction increased up to 2 -fold in the presence of CFO+MTX, NFO+MTX, and $\mathrm{ZFO}+\mathrm{MTX}$ at a $10 \mu \mathrm{g} / \mathrm{mL}$ dose $(p<0.01)$, whereas FeO+MTX exhibited a 9-fold increase in necrotic cells $(p<0.005)$. Free drugs (DOX and MTX, $5 \mu \mathrm{M}$ each) used as controls resulted in $33.07 \pm 3.72$ and $36.25 \pm 3.23 \%$ of apoptotic cells $(p<0.01)$, respectively.

In HT144 cells, $42.15 \pm 3.45$ to $63.62 \pm 3.51 \%$ of apoptotic cells $(p<0.05)$ were observed in the presence of DOX-loaded NPs $(5 \mu \mathrm{g} / \mathrm{mL})$ with the highest apoptotic fraction of $63.66 \pm 3.5 \%$ upon NFO+DOX treatment. An increase in apoptotic cells up to 1.3 - and 1.7 -fold $(p<0.01)$ was observed in $\mathrm{CFO}$ and $\mathrm{FeO}+\mathrm{DOX}$, respectively, at a $10 \mu \mathrm{g} / \mathrm{mL}$ dose. Alternatively, a significantly $(p<0.01)$ high cell death $(9.6$ - to 14 -fold increase in necrotic cells) was observed in ZFO and NFO+DOX nanocarriers, respectively. In the presence of MTX-loaded NPs, CFO and ZFO showed the maximum amount of apoptotic cells (i.e., $66.57 \pm 1.39$ and $60.52 \pm 3.81 \%$ respectively, $p<0.005$ ) at a $5 \mu \mathrm{g} / \mathrm{mL}$ concentration. At a higher dose, the percent of apoptotic cells increased up to 1.5 -fold in $\mathrm{FeO}, \mathrm{CFO}$, and NFO+MTX $(p<0.005)$. ZFO+MTX, however, caused maximum cell death with a 12-fold increase in necrotic cells. DOX and MTX controls caused $68.05 \pm 5.55$ and $59.13 \pm 3.93 \%$ of apoptosis, respectively $(p<0.001)$.

In both cell lines, PMA-coated NPs showed higher cellular viability after $3 \mathrm{~h}$ of treatment at a $10 \mu \mathrm{g} / \mathrm{mL}$ dose $(\mathrm{HepG} 2=$ $82.22 \pm 5.92$ to $94.74 \pm 2.03 \%$; HT144 $=93.36 \pm 5.11$ to $95.91 \pm 5.73 \%$ ), indicating biocompatibility of NPs-PMA at a given dose and treatment time.

\section{Cells undergo oxidative stress upon treatment with functionalized $\mathrm{MFe}_{2} \mathrm{O}_{4} \mathrm{NPs}$}

Generation of ROS has been associated with DNA damage, inflammation, apoptosis and senescence in cells [41]. The 2',7'dichlorodihydrofluorescein diacetate $\left(\mathrm{H}_{2}\right.$-DCFDA) assay was used to determine cellular ROS production in HepG2 and HT144 cells upon treatment with NPs over a period of time. Cells were exposed to NPs+DOX and NPs+MTX at $\mathrm{IC}_{50}$ concentrations and the increase in fluorescence was determined relative to untreated control cells over a time interval (0-45 min). Several studies have indicated that spinel ferrite $\mathrm{MFe}_{2} \mathrm{O}_{4}(\mathrm{M}=\mathrm{Fe}, \mathrm{Co}, \mathrm{Ni}, \mathrm{Zn})$ NPs cause cytotoxicity via oxida- tive stress which results in damage to the cell membrane, proteins, and DNA [41-43]. However, how NPs are processed inside the cell is also a contributing factor in ROS production [44]. For example, metallic NPs transported to lysosomes produce more ROS due to enhanced acidic degradation as compared to those remaining in the cytosol [45]. Besides, the intrinsic antioxidant potential of various cells also contributes to biocompatibility and extent of ROS generation via metallic NPs $[46,47]$.

In the present work, free DOX and MTX produced nonsignificant ROS in both cell lines, which significantly enhanced upon NP-mediated drug delivery. An increase in ROS production was observed in the first 5 min of treatment and steadily increased over time. NPs+DOX produced a significant amount of ROS $(p<0.05$ ) in HepG2 cells (Figure 6a) after 35-45 min of treatment. Conversely, NPs+MTX showed significant $(p<0.05)$ results after $20-45 \mathrm{~min}$ of exposure. Drug-loaded NPs exhibited 1.6- to 2-fold ROS production in HepG2 cells compared to free drug controls. HT144 cells, however, were more susceptible to oxidative damage via NPs+drugs and free drug controls compared to HepG2 cells. Both NPs+DOX and NPs+MTX started to produce a significant $(p<0.05)$ ROS amount at $5 \mathrm{~min}$ exposure time with 2- to 3 -fold increased effect compared to free drug controls. Lower sensitivity of HepG2 cells towards oxidative stress can be attributed to the presence of xenobiotic detoxification and antioxidant mechanisms [47].

\section{Functionalized $\mathrm{MFe}_{2} \mathrm{O}_{4} \mathrm{NPs}$ cause cell cycle arrest in cancer cells}

Evidence of oxidative damage in treated cells may indicate DNA damage and possible effects on cell cycle progression, causing damaged cells to accumulate in sub-G1, G1, S, or $\mathrm{G} 2 / \mathrm{M}$ phases of the cell cycle [48]. To determine the effects of drug-loaded $\mathrm{MFe}_{2} \mathrm{O}_{4}$ NPs on the cell cycle progression, HepG2 and HT144 cells treated with NPs at $\mathrm{IC}_{50}$ doses were analyzed by flow cytometry. The data obtained from each sample was compared to NTC (Figure 6b).

In HepG2 cells, all NPs+DOX, FeO+MTX, and CFO+MTX showed a significant $(p<0.005) \mathrm{G} 1$ arrest resulting in a decreased cellular population in S and G2/M phases $(p<0.05)$. Similar observations were made in free DOX $(0.2 \mu \mathrm{M})$ control, which was consistent with a previous report [49]. In contrast, NFO+MTX and ZFO+MTX exhibited a delay in the S phase $(p<0.005)$ causing inhibition of cellular replication and progression towards G2/M. Furthermore, a significant $(p<0.05) \mathrm{G} 2 / \mathrm{M}$ phase arrest in $\mathrm{FeO}+\mathrm{MTX}$ and ZFO+MTX was also observed. Free MTX $(0.2 \mu \mathrm{M})$ control caused G1 and $\mathrm{S}$ phase arrest $(p<0.005)$ with reduced cells in the $\mathrm{G} 2 / \mathrm{M}$ phase 
a.

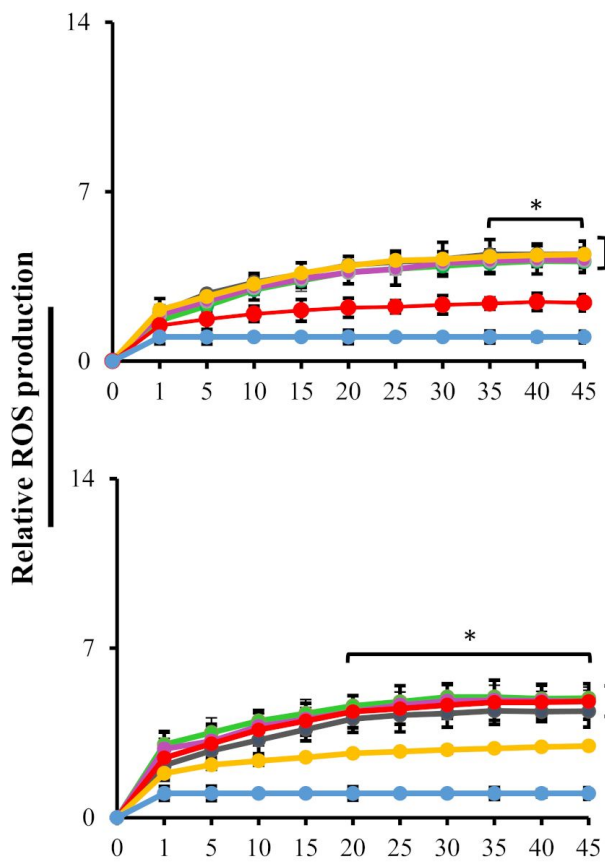

HT144
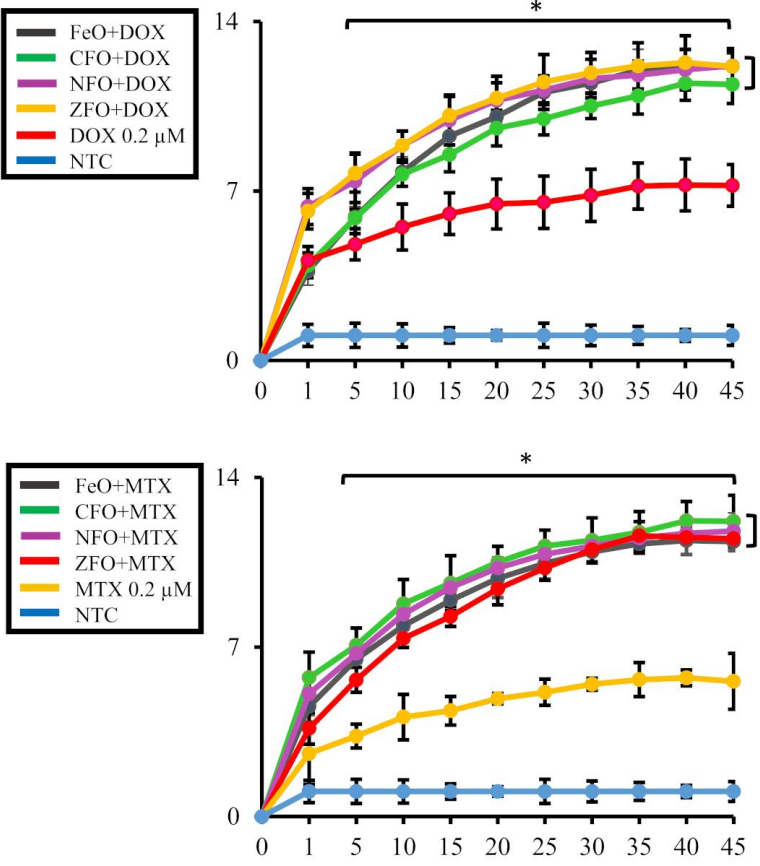

b.

Treatment (minutes)

\section{HepG2}
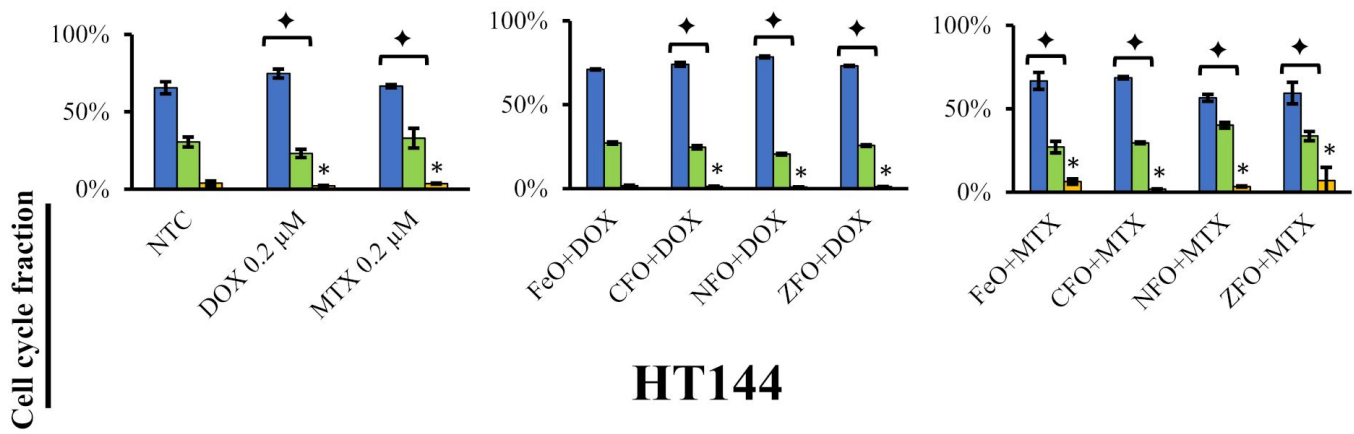

\section{HT144}
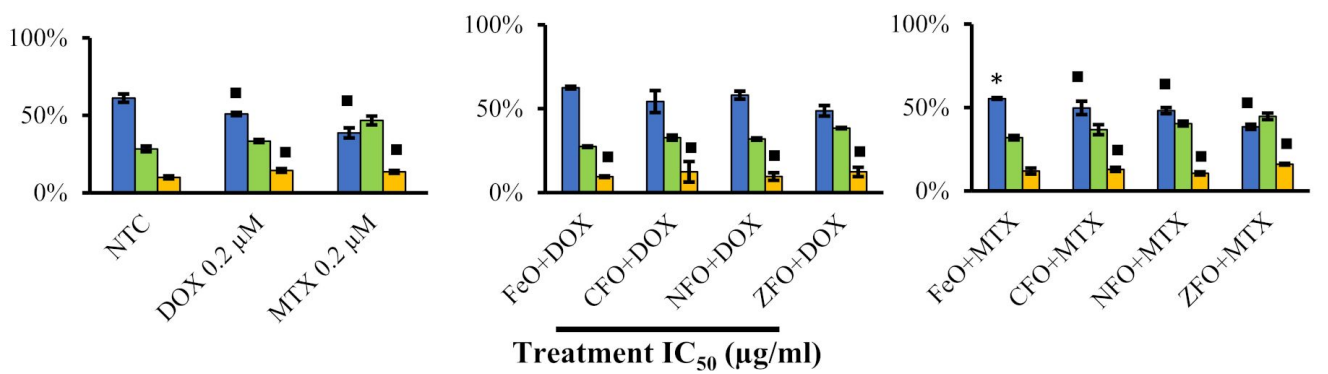

Figure 6: (a) Intracellular ROS generation in HepG2 and HT144 cells upon treatment with drug-loaded (DOX and MTX) MFe $2 \mathrm{O}_{4}(\mathrm{M}=\mathrm{Fe}, \mathrm{Co}, \mathrm{Ni}, \mathrm{Zn}$ ) NPs for 0-45 min at IC 50 doses. Free drugs (DOX and MTX, $0.2 \mu \mathrm{M}$ each) and NTC were included as controls. ROS generation in cells was determined relative to NTC. Data was represented as mean \pm SD of experimental triplicates. $p<0.05$ (one asterisk), paired two-tailed $t$-test when compared to NTC. (b) Effect of drug-loaded $\mathrm{MFe}_{2} \mathrm{O}_{4}$ NPs on cell cycle progression in HepG2 and HT144 cells determined by flow cytometry. Cells were exposed to $\mathrm{IC}_{50}$ doses of NPs for $24 \mathrm{~h}$. Untreated cells and free drugs (DOX and MTX, $0.2 \mu \mathrm{M}$ ) were included as controls. $p<0.05$ (one asterisk), $p<0.01$ (black square symbol), $p<0.005$ (black diamond symbol), paired two-tailed $t$-test when compared to NTC. 
$(p<0.05)$. Methotrexate has been previously reported to cause cytotoxicity in the $\mathrm{S}$ phase and stop progression from $\mathrm{G} 1$ to $\mathrm{S}$ phase [50].

In HT144 cells, all DOX-loaded NPs showed a non-significant $S$ phase arrest except $\mathrm{FeO}+\mathrm{DOX}$ which caused G1 arrest. $\mathrm{CFO}+\mathrm{DOX}$ and $\mathrm{ZFO}+\mathrm{DOX}$ were also responsible for $\mathrm{G} 2 / \mathrm{M}$ arrest $(p<0.01)$ accompanied by a lower cell population at G1 Comparably, free DOX control also caused a G2/M arrest $(p<0.01)$ and reduced the number of cells in the G1 phase $(p<0.01)$. All MTX-loaded NPs and free MTX control caused $\mathrm{G} 2 / \mathrm{M}$ arrest $(p<0.01)$ in cells with a non-significant S phase arrest, lowering the cellular population in the $\mathrm{G} 1$ phase $(p<0.01)$.

The obtained flow cytometry results from drug-loaded NPs were comparable to free drug controls $(0.2 \mu \mathrm{M})$. However, considering that the amount of attached drug with $\mathrm{IC}_{50}$ doses of NPs was much lower than $0.2 \mu \mathrm{M}$ (as mentioned in Table 8), it was speculated that nanocarriers amplified the effects due to improved and efficient drug delivery at a much lower dose compared to free drug controls.

\section{Functionalized $\mathrm{MFe}_{2} \mathrm{O}_{4} \mathrm{NPs}$ cause genotoxicity in treated cells}

The alkaline comet assay was performed to determine the genotoxicity of drug-loaded NPs in HepG2 and HT144 cells (Figure 7a). The olive tail moment was measured for each sample and a relative calculation with respect to NTC was performed as a measurement of DNA damage (Figure 7b). The genotoxic effect of NPs may arise from their direct interaction with DNA or enhanced ROS production by cellular components. If unrepaired or misrepaired, these lesions may contribute to replication errors and gene or chromosomal alterations [51].

The genotoxicity of spinel ferrite NPs has been reported earlier $[52,53]$. However, other factors such as NP size and ligand used for functionalization may contribute to a genotoxic activity Smaller NPs $(<50 \mathrm{~nm})$ have large surface area which increases their biological interactions and hence genotoxic potential [54] Polymeric coatings, on the other hand, are aimed to enhance colloidal stability and facilitate the interaction between NPs a plasma membrane associated proteins [55]. In addition, the charge of polymeric coatings also governs NP uptake by cells. Positively charged polymers have been reported to enhance genotoxicity due to better internalization of NPs via the plasma membrane (electrostatic interaction) and direct interaction with the nucleus and DNA. On the other hand, negatively charged coating such as PMA has no effect on genotoxicity [56].
In HepG2 cells, $\mathrm{FeO}+\mathrm{DOX}$ and $\mathrm{CFO}+\mathrm{DOX}$ showed maximum genotoxicity with relative tail moment values of $6.41 \pm 1.75$ and $4.68 \pm 2.45(p<0.01)$, respectively, which were higher (up to 2 -fold) than that of free DOX control $(2.77 \pm 2.35, p<0.05)$. Among MTX nanocarriers, CFO+MTX and ZFO+MTX were highly genotoxic $(p<0.005)$ having relative tail moment values of $4.58 \pm 4.23$ and $4.21 \pm 4.93$, respectively. The results were up to 1.6-fold higher than that of free MTX control $(2.82 \pm 3.24 ; p<0.01)$.

In HT144 cells, maximum genotoxicity $(p<0.005)$ was observed in $\mathrm{CFO}+\mathrm{DOX}$ and $\mathrm{ZFO}+\mathrm{DOX}$ with relative tail moment values of $6.72 \pm 1.44$ and $5.44 \pm 1.06$, respectively. The results were enhanced up to 2.4-fold compared to free DOX, where a relative tail moment of $2.78 \pm 1.66$ $(p<0.01)$ was observed. Relative tail moment values in CFO+MTX and ZFO+MTX were $3.98 \pm 1.09$ and $4.44 \pm 0.88$ $(p<0.005)$, respectively, which were almost 2 -fold higher than that of free MTX control $(2.22 \pm 1.21 ; p<0.05)$. The obtained results were therefore indicative of enhanced genotoxic behavior in cancer cells upon NP-mediated drug delivery.

\section{Functionalized $\mathrm{MFe}_{2} \mathrm{O}_{4} \mathrm{NPs}$ cause DNA fragmentation in treated cells}

Both HepG2 and HT144 cells showed apoptotic DNA fragmentation (Figure 7c) upon treatment with drug-loaded NPs at $\mathrm{IC}_{50}$ doses for $24 \mathrm{~h}$. Distinct bands of $180 \mathrm{bp}$ were visualized on a $2 \%$ agarose gel, which indicates shearing of DNA as a result of apoptosis in treated cells. These findings indicated that drugloaded NPs cause cytotoxicity in cancer cells via oxidative stress leading to apoptosis and DNA fragmentation.

\section{Functionalized $\mathrm{MFe}_{2} \mathrm{O}_{4} \mathrm{NPs}$ alter Ki-67 and p53 expression in treated cells}

p53 is a tumor suppressor protein also known as the "guardian of the genome". It is involved in downstream regulation of genes involved in apoptosis, DNA repair, and cell cycle arrest. Overexpression of p53 is triggered by stress stimuli, such as hypoxia, ROS, ionizing radiations, and carcinogens. Normal cells have a low expression of p53 but its half-life may increase up to several hours under stress, resulting in elevated expression [57]. Enhanced expression of p53 in response to cellular stress has been associated with cell cycle regulation. It causes G1 arrest by inhibiting cyclin D and stimulating p21 expression. It is also involved in repairing lethal DNA damages (doublestranded breaks) via Gadd45 by arresting cells at G1. The G2 arrest occurs by $\mathrm{p} 53$-mediated reduction in cyclin $\mathrm{B} 1$ and the $\mathrm{S}$ phase arrest happens by the regulation of mitotic spindle checkpoints. Extensive DNA damage, however, leads to apoptosis [58]. 
a. HepG2

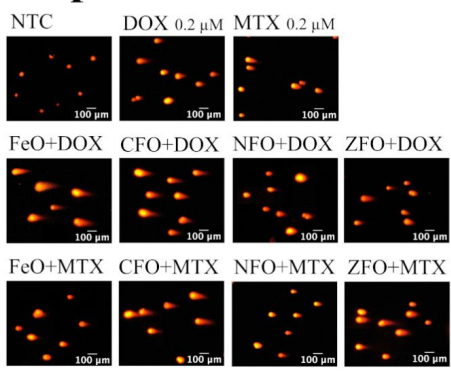

HT144

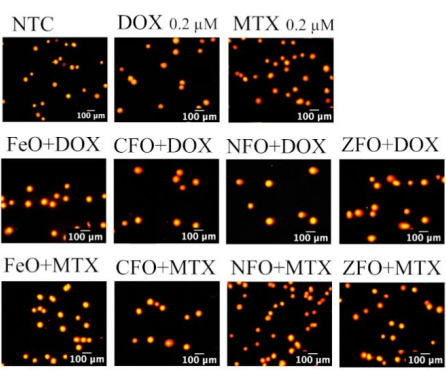

b.

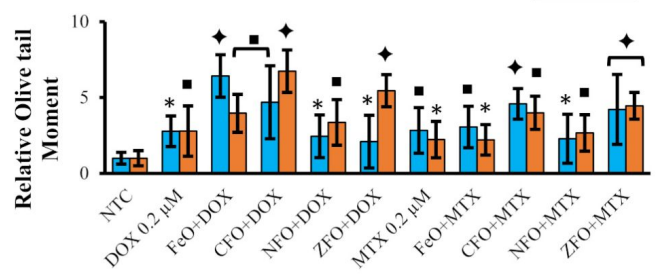

c.

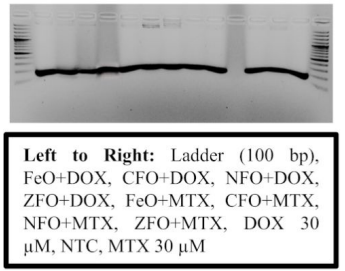

e.

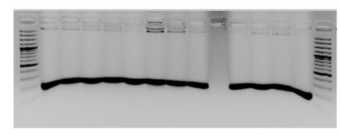

Left to Right: Ladder (100 bp), FeO+DOX, CFO+DOX, NFO+DOX, ZFO+DOX, $\mathrm{FeO}+\mathrm{MTX}, \mathrm{CFO}+\mathrm{MTX}$ $30 \mu \mathrm{M}, \mathrm{MTX} 30 \mu \mathrm{M}$

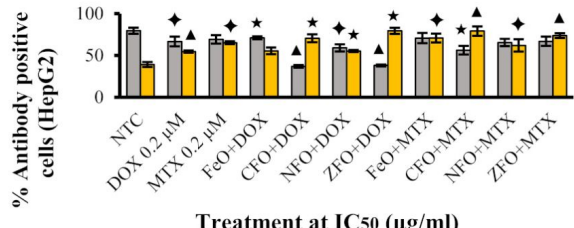

\section{d. HepG2}

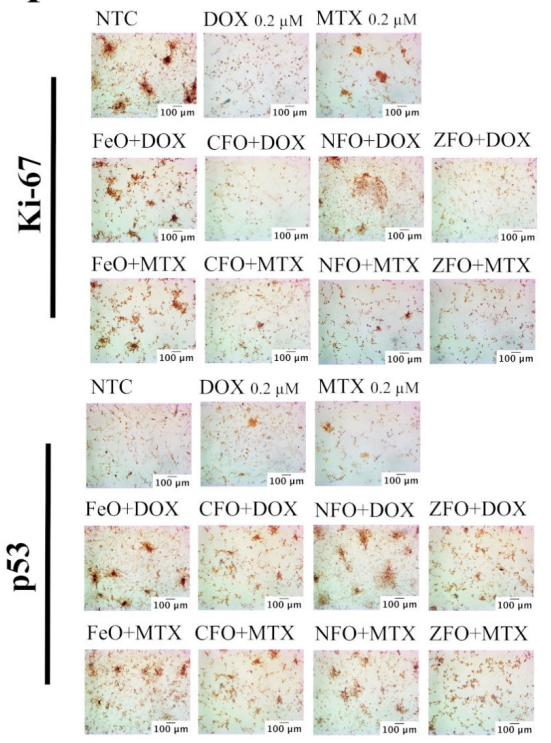

HT144
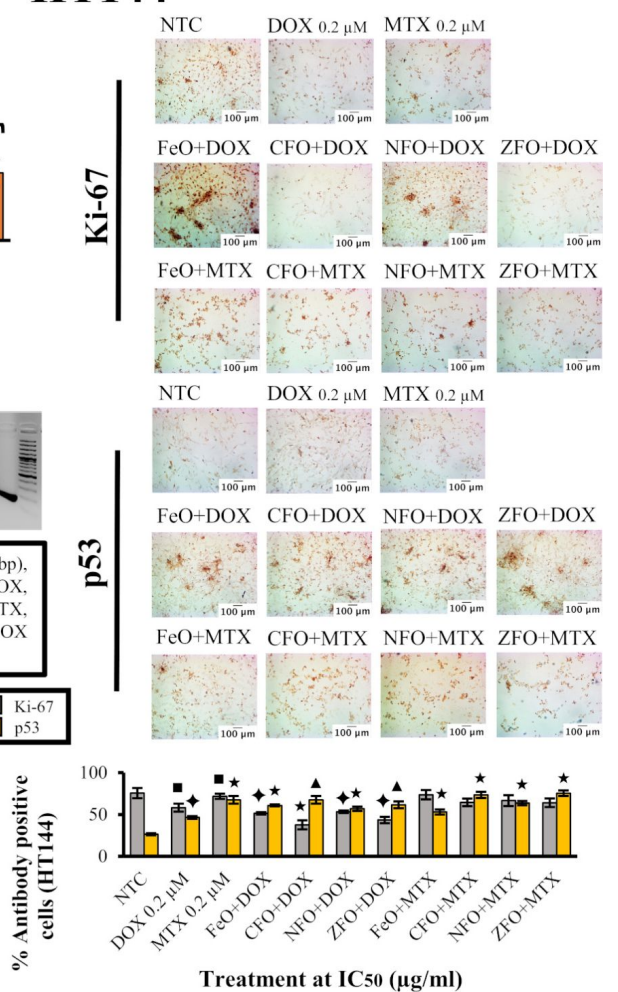

Figure 7: (a) Comet images of HepG2 and HT144 cells treated with drug-loaded (DOX and MTX) $\mathrm{MFe}_{2} \mathrm{O}_{4}(\mathrm{M}=\mathrm{Fe}, \mathrm{Co}, \mathrm{Ni}, \mathrm{Zn}) \mathrm{NPs}$ at IC 50 doses for $1 \mathrm{~h}$. Controls included free drugs (DOX and MTX, $0.2 \mu \mathrm{M}$ each) and NTC. Cells were stained with propidium iodide $(5 \mu \mathrm{g} / \mathrm{mL}) . \mathrm{Magnification}=200 \times$, scale bar $=100 \mu \mathrm{m}$. (b) Olive tail moment values as a measurement of DNA damage (mean \pm SD) were calculated relative to NTC for each sample. $p<0.05$ (one asterisk), $p<0.01$ (black square symbol), and $p<0.005$ (black diamond symbol), paired two-tailed $t$-test when compared to NTC. (c) From left to right: apoptotic DNA fragmentation in HepG2 and HT144 cells after treatment with NPs+drugs for $24 \mathrm{~h}$ at IC 50 doses. Free drugs (DOX and MTX, $30 \mu \mathrm{M}$ ) and NTC were included as controls. DNA samples were electrophoresed on a $2 \%$ agarose gel for $2 \mathrm{~h}$ at $50 \mathrm{~V}$ along with a DNA ladder (100 bp). (d) Microscopy images of immunocytochemical (ICC) staining of treated (IC 50 doses of NPs+drugs for $24 \mathrm{~h}$ ) HepG2 and HT144 cells with Ki-67 and p53 mouse monoclonal antibodies. Controls included NTC and free drugs (DOX and MTX, $0.2 \mu M)$. Magnification $=200 \times$, scale bar $=$ $100 \mu \mathrm{m}$. (e) Bar charts representing the expression levels of Ki-67 and p53 antibodies in treated HepG2 and HT144 cells. Antibody positive cells were counted in treated and untreated samples and percentages were calculated (mean \pm SD). $p<0.01$ (black square symbol), $p<0.005$ (black diamond symbol), $p<0.001$ (black star symbol), and $p<0.0005$ (black triangle symbol), paired two-tailed $t$-test upon comparison with NTC. 
Conversely, Ki-67 is an important proliferative and prognostic cancer biomarker expressed in the nucleus during the cell cycle. It is important for cell division and biosynthesis of ribosomal RNA and it is variably expressed throughout the cell cycle (high in the G2/M phase and low in G1 and S phases). High expression of Ki-67 usually contributes to poor survival rates in cancer patients [59].

In this study, the effect of the treatment with drug-loaded $\mathrm{MFe}_{2} \mathrm{O}_{4}(\mathrm{M}=\mathrm{Fe}, \mathrm{Co}, \mathrm{Ni}, \mathrm{Zn}) \mathrm{NPs}\left(\mathrm{IC}_{50}\right.$ doses$)$ on cancer biomarker expression levels was evaluated via ICC (Figure 7d). Untreated cells exhibited a high expression of Ki-67 (HepG2 = $79.62 \pm 3.72 \% ;$ HT144 = $75.67 \pm 6.14 \%$ ), indicating a high proliferative potential of cancer cells, whereas the expression of p53 was relatively low $($ HepG2 $=39.23 \pm 2.91 \%$; HT144 $=$ $26.44 \pm 1.25 \%$ ) (Figure 7e).

Upon treatment, p53 expression was elevated which was potentially responsible for cell cycle arrest and apoptosis. In HepG2 cells, DOX-loaded CFO and ZFO nanocarriers showed a maximum p53 expression of $70.43 \pm 4.82$ and $79.47 \pm 3.65 \%$ $(p<0.001)$, respectively. Similar results were observed in MTX-loaded NPs, where a maximum p53 expression of $79.13 \pm 5.61$ and $73.65 \pm 2.93 \%(p<0.0005)$ was observed in $\mathrm{CFO}+\mathrm{MTX}$ and ZFO+MTX, respectively. An increase in expression was observed when compared to free drug controls, where only $54.61 \pm 1.32 \%$ and $65.33 \pm 1.71 \%$ of p53 expression was observed in DOX and MTX, respectively $(p<0.005)$. On the other hand, a decrease in Ki-67 expression was observed in treated cells, indicating a potential role in the inhibition of cellular proliferation. A significantly stronger $(p<0.005)$ decrease in $\mathrm{Ki}-67$ expression was observed in $\mathrm{CFO}$ and $\mathrm{ZFO}$ nanocarriers $(\mathrm{CFO}+\mathrm{DOX}=36.9 \pm 1.57 \%$, ZFO+DOX $=38.1 \pm 1.17 \%$, CFO $+\mathrm{MTX}=56.3 \pm 5.23 \%$, and $\mathrm{ZFO}+\mathrm{MTX}=$ $66.9 \pm 5.55 \%)$. Free drug controls, however, reduced Ki-67 expression by approx. $12 \%(\mathrm{DOX}=66.6 \pm 5.82 \%$, MTX $=$ $69.2 \pm 5.14 \%$ ) compared to NTC.

Similar observations were made in HT144 cells where CFO and ZFO nanocarriers were highly effective. Among DOX nanocarriers, CFO+DOX showed the highest p53 expression of $67.66 \pm 4.66 \%(p<0.0005)$ and the lowest Ki-67 expression of $37.75 \pm 5.31 \%(p<0.001)$. Conversely, p53 and Ki-67 levels were $46.63 \pm 1.65 \%(p<0.005)$ and $58.27 \pm 4.86 \%(p<0.01)$ in the free DOX control. Amidst MTX nanocarriers, Ki-67 levels of $64.44 \pm 4.62 \%$ and $64.15 \pm 5.21 \%$ were observed in $\mathrm{CFO}+\mathrm{MTX}$ and ZFO+MTX, respectively. Both nanocarriers also elevated $\mathrm{p} 53$ expression up to $75 \%(p<0.001)$. Free MTX, however, showed Ki-67 and p53 levels of $71.82 \pm 3.11 \%$ $(p<0.01)$ and $67.66 \pm 4.68 \%(p<0.001)$, respectively, indicating a better performance of drug-loaded NPs. The obtained results also suggested a stronger inhibition of Ki-67 by DOXloaded NPs as compared to NP+MTX in both cell lines.

In both cell lines, a decrease in $\mathrm{Ki}-67$ expression may indicate a low proliferative potential of cancer cells after treatment with nanocarriers. However, a variable expression of Ki-67 during the cell cycle may also affect these findings [60]. Flow cytometry results revealed that NPs+DOX caused G1 and S phase arrest in HepG2 and HT144 cells, respectively, which may result in a relatively low expression of Ki-67 in these treatment groups and a comparatively higher expression in samples showing G2/M arrest in the cell cycle. Furthermore, irreparable DNA damage (double-stranded breaks) also contributes towards irreversible G1 arrest and senescence, which decreases the proliferative capacity of the cells [61]. Since the effect of Ki-67 on cell survival and proliferation has not been clearly understood yet [59], it is not possible to elucidate the effect of certain therapeutic interventions on this biological event without extensive investigations.

\section{Functionalized $\mathrm{MFe}_{2} \mathrm{O}_{4} \mathrm{NPs}$ reduce cellular viability in HepG2 and HT144 3D spheroid models}

The use of three-dimensional (3D) spheroid models for highthroughput drug screening in vitro is favored due to their close resemblance to in vivo tumors. Moreover, they possess several tumor hallmarks, such as hypoxia, cellular interaction, drug resistance, and dense extracellular matrix, allowing for better pathobiological studies of human cancers [62].

Here, spheroids of HepG2 and HT144 cells were grown for cytotoxicity assessment of drug-functionalized $\mathrm{MFe}_{2} \mathrm{O}_{4} \mathrm{NPs}$ ( $5 \mu \mathrm{g} / \mathrm{mL}$ ). The obtained HepG2 and HT144 spheroids had average diameters of $420 \pm 21.5$ and $582 \pm 72 \mu \mathrm{m}$, respectively, which reached the maximum value at the 14th day $(\mathrm{HepG} 2=$ $450 \pm 16.33$ and HT144 = $713 \pm 81.3 \mu \mathrm{m})$. HepG2 formed compactly packed spheroids, whereas HT144 spheroids were loosely bound (Figure 8).

In HepG2 spheroids, a slight reduction in the spheroid diameter was observed after treatment with drug-loaded NPs. The spheroids were also not highly disintegrated (Figure 8). ZFO+DOX and CFO+MTX, among DOX and MTX nanocarriers, caused a maximum reduction $(p<0.005)$ in spheroid diameter up to $20 \mu \mathrm{m}$ (Figure 9a) at the 14th day. A slight disintegration of spheroids was also observed at the 7th and 14th day of treatment. Alternatively, free DOX and MTX reduced the diameter up to $30 \mu \mathrm{m}(p<0.005)$ without prominent spheroid disintegration. The cellular viability determined via the trypan blue assay at the 14th day indicated up to $57 \pm 3.1 \%(p<0.01)$ of cell death in treated spheroids compared to $37.5 \pm 2.3$ and 


\section{HepG2}

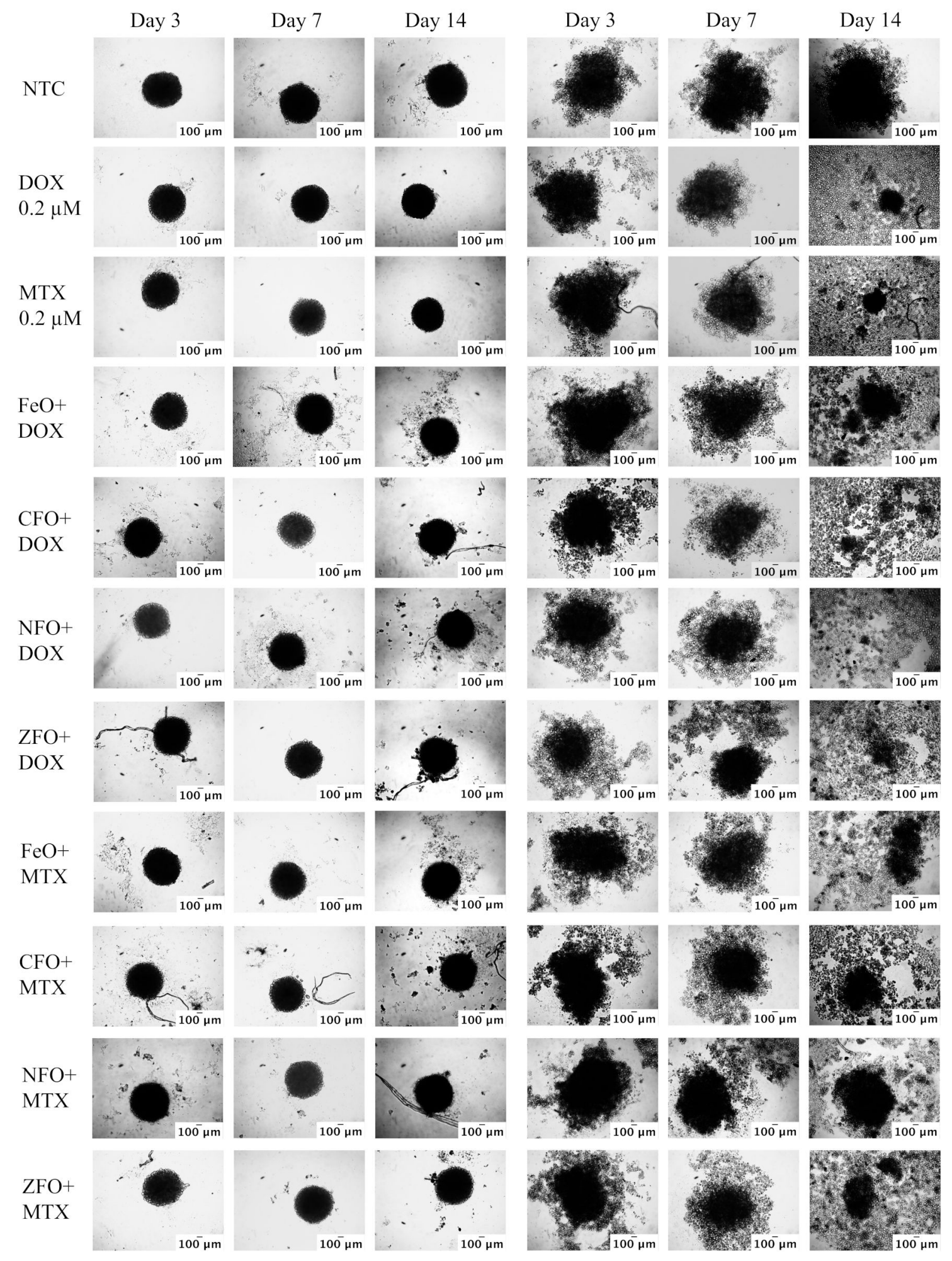

Figure 8: Microscopy images (magnification $=100 x$, scale bar $=100 \mu \mathrm{m}$ ) of HepG2 and HT144 3D spheroids grown for three days and then treated with drug-loaded (DOX and MTX) $\mathrm{MFe}_{2} \mathrm{O}_{4}(\mathrm{M}=\mathrm{Fe}, \mathrm{Co}, \mathrm{Ni}, \mathrm{Zn}$ ) NPs at $5 \mu \mathrm{g} / \mathrm{mL}$ for 14 days. Controls included free drugs (DOX and MTX, $0.2 \mu \mathrm{M}$ each) and NTC. The medium was replenished after regular intervals and photographs were taken after three, seven, and fourteen days to observe changes in spheroid morphology. 
a.

HepG2

$\square 3$ days $\square 7$ days $\square 14$ days

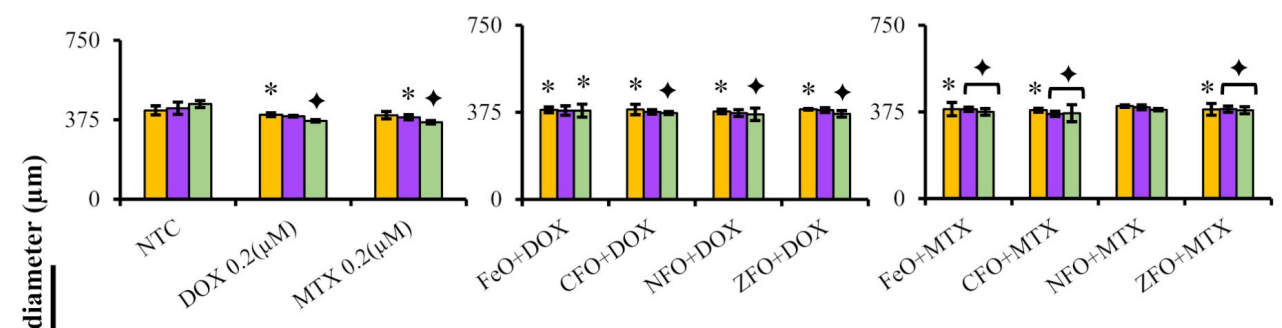

HT144

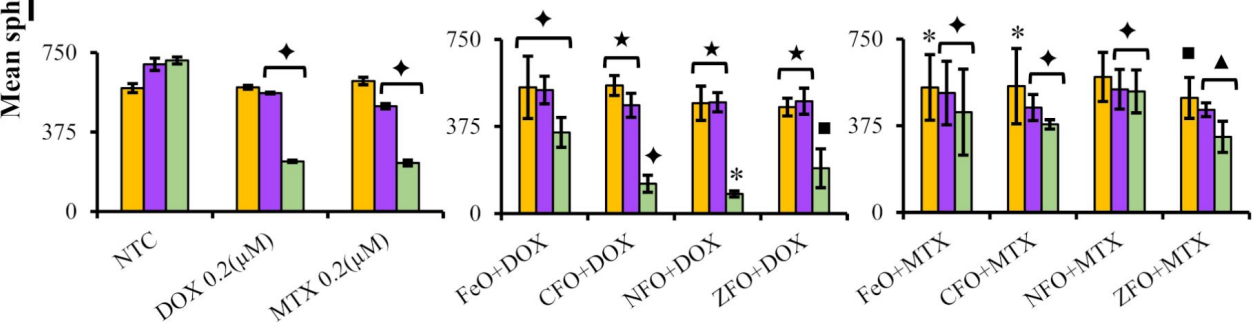

Treatment $(5 \mu \mathrm{g} / \mathrm{ml})$

b.

$\square$ Live cells $\square$ Dead cells

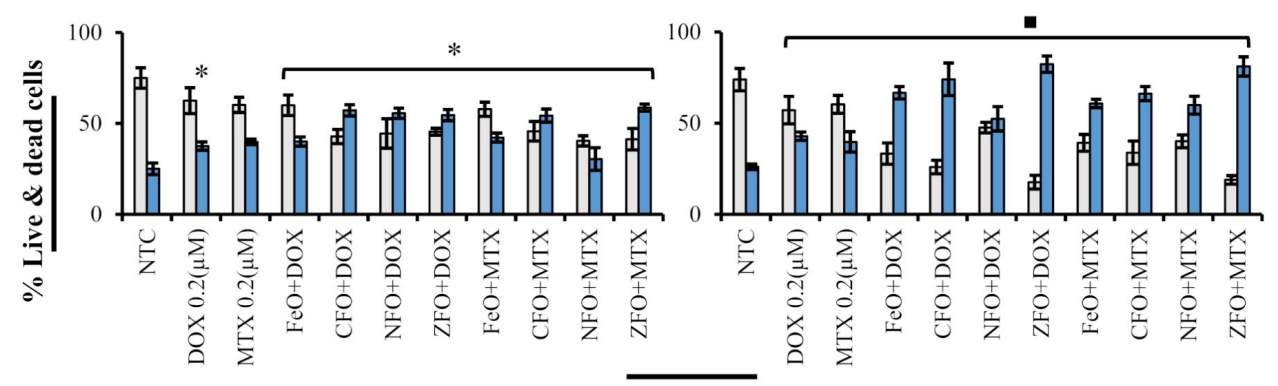

Treatment $(5 \mu \mathrm{g} / \mathrm{ml})$

c.

$\square$ HepG2 $\square$ HT144

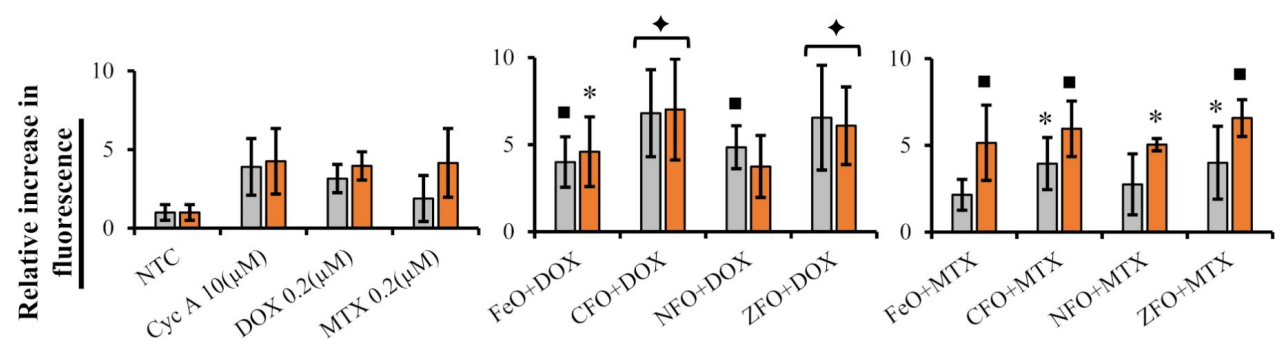

Treatment $\mathrm{IC}_{50}(\mu \mathrm{g} / \mathrm{ml})$

Figure 9: (a) Bar charts indicating changes in HepG2 and $\mathrm{HT} 144$ spheroid diameters upon treatment with drug-loaded (DOX and MTX) MFe $\mathrm{O}_{4}$ $(\mathrm{M}=\mathrm{Fe}, \mathrm{Co}, \mathrm{Ni}, \mathrm{Zn}) \mathrm{NPs}$ at $5 \mu \mathrm{g} / \mathrm{mL}$ for three, seven, and fourteen days. Controls included free drugs (DOX and MTX, $0.2 \mu \mathrm{M}$ each) and NTC. After each time point, an average spheroid diameter was calculated by the ImageJ software. The plotted data indicates mean \pm SD of multiple readings covering maximum and minimum diameter ranges of spheroids. (b) From left to right: bar charts indicating viability and death percentage in treated HepG2 and HT144 3D spheroids after 14 days. Live and dead cells in each sample were counted using the trypan blue assay. The data plotted indicates mean $\pm \mathrm{SD}$ of three replicates. $p<0.05$ (one asterisk), $p<0.01$ (black square symbol), $p<0.005$ (black diamond symbol), $p<0.001$ (black star symbol), and $p<0.0005$ (black triangle symbol), paired two-tailed $t$-test when compared to NTC. (c) Bar charts represent multidrug resistance (MDR) pump inhibition (mean \pm SD) in HepG2 and HT144 cells treated with NPs+drugs for $24 \mathrm{~h}$. Controls included NTC, free drugs (DOX and MTX, $0.2 \mu \mathrm{M}$ each), and the MDR inhibitor cyclosporin A (Cyc $A=10 \mu \mathrm{M})$. The inhibition of MDR pump activity was determined by the increase in fluorescence relative to NTC. $p<0.05$ (one asterisk), $p<0.01$ (black square symbol), and $p<0.005$ (black diamond symbol), paired two-tailed $t$-test when samples were compared to free drug controls. 
$39.8 \pm 1.5 \%$ in free DOX and MTX controls, respectively (Figure 9b).

In HT144 spheroids, CFO+DOX and ZFO+MTX, among DOX and MTX nanocarriers, produced a significant reduction in spheroid diameter (Figure 9a) at the 14th day $(423 \mu \mathrm{m}$, $p<0.005$ and $168 \mu \mathrm{m}, p<0.0005$, respectively) with $74 \pm 8.9$ and $81 \pm 5.3 \%(p<0.01)$ of cellular death (Figure $9 \mathrm{~b})$. The cells lost their compactness and started to disaggregate after three days of treatment, which increased with time (Figure 8). The average reduction in the diameter of spheroids after treatment with free DOX and MTX samples was 350 and $387 \mu \mathrm{m}$ $(p<0.01)$ with $43 \pm 2.3$ and $39.7 \pm 5.6 \%(p<0.01)$ of cell death, respectively. The obtained results suggested better internalization of drug-loaded NPs compared to free drugs.

\section{Functionalized $\mathrm{MFe}_{2} \mathrm{O}_{4} \mathrm{NPs}$ cause inhibition of MDR pump activity in treated HepG2 and HT144 cells}

Due to the overexpression of P-glycoprotein (P-gp), cancer cells possess the ability to efflux chemotherapeutic drugs, a phenomenon known as MDR. P-glycoprotein belongs to the ABCB1 family of $\mathrm{ABC}$ proteins and is involved in the efflux of doxorubicin, paclitaxel, vincristine, rhodamine, and etoposide [63] Conversely, multidrug resistance-associated protein 1 (MRP1) is a member of the ABCC1 family, responsible for the efflux of xenobiotics and hydrophobic drugs, namely methotrexate, vinca alkaloids, anthracyclines, antiandrogens, and heavy metals. Both multidrug resistance protein 1 (MDR1) and MRP1 proteins are majorly responsible for lowering the therapeutic outcomes of chemotherapy [64].

The present study was conducted to evaluate the role of drugfunctionalized $\mathrm{MFe}_{2} \mathrm{O}_{4} \mathrm{NPs}$ in hindering MDR pump activity in HepG2 and HT144 cells after a $24 \mathrm{~h}$ treatment at $\mathrm{IC}_{50}$ doses. The retention of the fluorometric dye was estimated relative to NTC (Figure 9c). Among DOX nanocarriers in HepG2, $\mathrm{CFO}+\mathrm{DOX}$ and $\mathrm{ZFO}+\mathrm{DOX}$ produced maximum significant inhibition of the MDR pump, with up to 6.8-fold $(p<0.005)$ dye retention compared to NTC. Similarly, among MTX nanocarriers, the highest dye retention of up to 4-fold was observed in CFO+MTX and ZFO+MTX $(p<0.05)$. Dye retention in free DOX and MTX was lower (3- and 1.9-fold, respectively). Cyclosporin A, used as positive control, caused inhibition of MDR up to 4-fold.

Similar results were obtained in HT144 cells. Among DOX nanocarriers, $\mathrm{CFO}+\mathrm{DOX}$ and $\mathrm{ZFO}+\mathrm{DOX}$ were responsible for the maximum inhibition of the MDR pump (up to 7-fold, $p<0.005$ ), whereas dye retention in free DOX was 3.9-fold compared to NTC. Amidst MTX nanocarriers, ZFO+MTX and
CFO+MTX proved to be the most efficient, with up to 6.5 -fold $(p<0.01)$ dye retention compared to free MTX, with a lower dye retention of 4.1 -fold.

The results indicated a possible role of drug-loaded CFO and ZFO NPs in combating MDR in cancer cells.

\section{Functionalized $\mathrm{MFe}_{2} \mathrm{O}_{4} \mathrm{NPs}$ showed higher $\mathrm{IC}_{50}$ in normal cells as compared to cancer cells}

The cytotoxicity of drug-loaded NPs was assessed in fresh human lymphocytes to determine their biocompatibility in vitro using the MTT assay. Freshly collected lymphocytes were exposed to varying concentrations $(1,10,25,50$, and $100 \mu \mathrm{g} / \mathrm{mL}$ ) of drug-loaded NPs for $24 \mathrm{~h}$. Untreated cells and free drug controls (DOX and MTX) at 0.04, 0.4, 1, 2, and $4 \mu \mathrm{M}$ (equivalent to drug attached with tested concentrations of NPs) were also included as controls.

The results indicated the cytotoxicity of drug-loaded NFO NPs in a dose-dependent manner, with percentage values of viability (highest to lowest) ranging from $75.37 \pm 2.41$ to $8.52 \pm 4.75$ in $\mathrm{NFO}+\mathrm{DOX}$ and $85.56 \pm 3.12$ to $17.52 \pm 9.46$ in NFO+MTX. All NPs+DOX were significantly cytotoxic $(p<0.05)$ at $25 \mu \mathrm{g} / \mathrm{mL}$ and at higher concentrations $(p<0.05)$, excluding NFO which was cytotoxic at $10 \mu \mathrm{g} / \mathrm{mL}$ as well $(p<0.05)$. DOX-loaded CFO and ZFO were the least cytotoxic compared to other NPs with \% viability values (from highest to lowest) ranging from $83.93 \pm 2.01$ to $20.91 \pm 6.42$ for $\mathrm{CFO}$ and $81.56 \pm 1.33$ to $19.74 \pm 5.91$ for ZFO at all doses (Figure 10b).

Among MTX-loaded NPs, all samples were significantly cytotoxic at $50 \mu \mathrm{g} / \mathrm{mL}$ and higher concentrations $(p<0.05)$. While NFO was cytotoxic $(p<0.005)$ even at $25 \mu \mathrm{g} / \mathrm{mL}, \mathrm{ZFO}$ and CFO loaded with MTX were the most biocompatible with $\%$ viability values (from highest to lowest) ranging from $88.67 \pm 5.01$ to $24.33 \pm 3.92$ and $87.81 \pm 1.60$ to $21.26 \pm 3.94$, respectively (Figure 10c) at all tested doses. Free drug controls (DOX and MTX) showed significant cytotoxicity $(p<0.05)$ at the highest dose of $4 \mu \mathrm{M}$ (Figure 10a).

The obtained results suggested an increased selectivity of nanocarriers towards cancer cells as previously reported [65], with $\mathrm{IC}_{50}$ values approximately 10-35 times higher (except NFO+DOX) in normal cells compared to cancer cells (Table 8).

\section{Conclusion}

The present research describes sonochemically synthesized, biocompatible, highly colloidal, drug- (DOX and MTX) functionalized $\mathrm{MFe}_{2} \mathrm{O}_{4}(\mathrm{M}=\mathrm{Fe}, \mathrm{Co}, \mathrm{Ni}, \mathrm{Zn}) \mathrm{NPs}$ for in vitro anticancer drug delivery. All nanocarriers showed significantly in- 


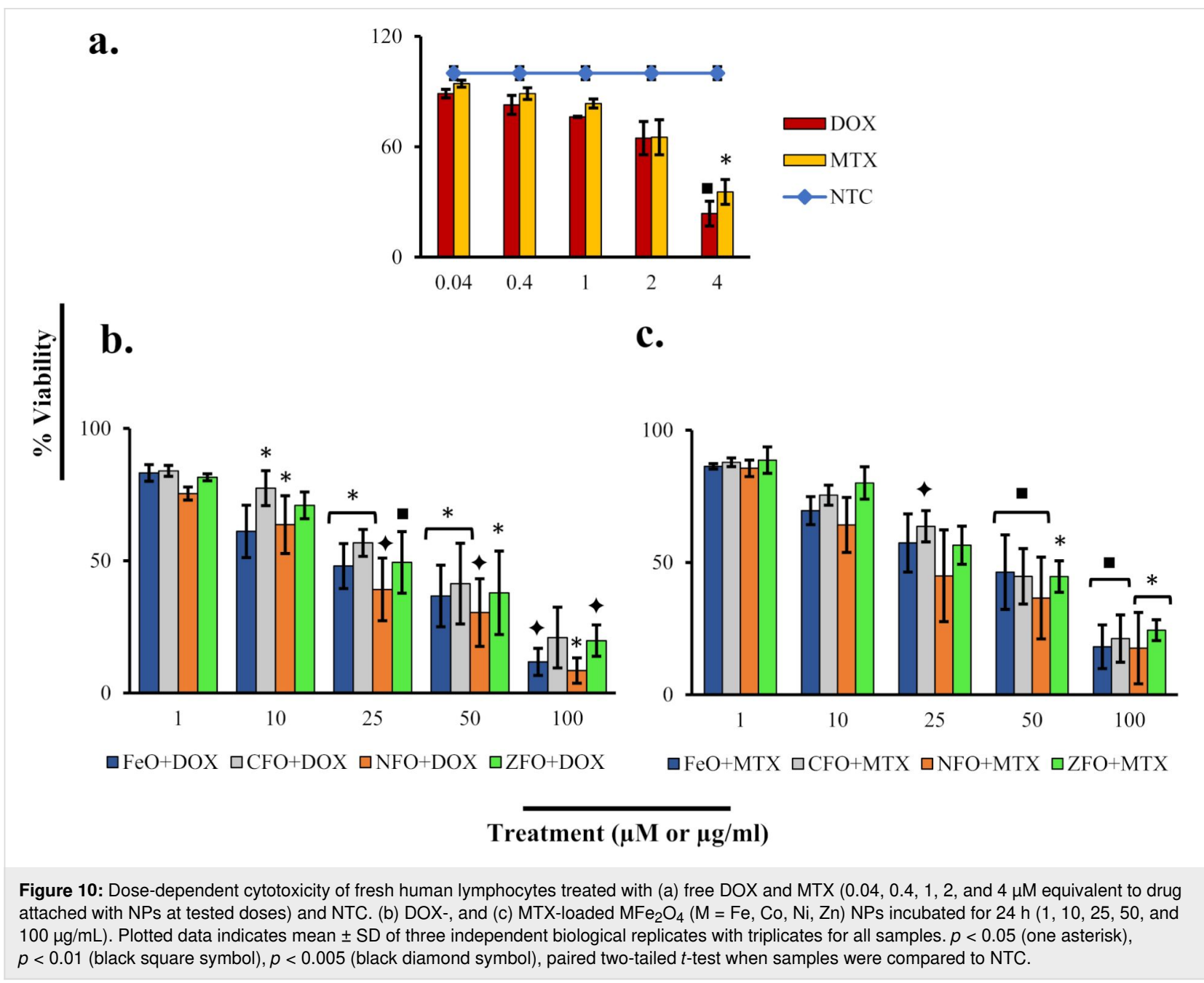

creased $(p<0.005)$ drug release at an acidic $\mathrm{pH}$ value $(\mathrm{pH} 5.5)$ compared to that at a physiological $\mathrm{pH}$ value $(\mathrm{pH} 7.4)$, indicating their specificity towards cancer cells. In vitro cytotoxicity analysis indicated increased cytotoxicity in a dose-dependent manner compared to free drugs, with $\mathrm{IC}_{50}$ values ranging from $0.81-3.97 \mu \mathrm{g} / \mathrm{mL}$ in cancer cells and $18.35-43.04 \mu \mathrm{g} / \mathrm{mL}$ in normal cells. Similarly, cytotoxicity screening in 3D spheroids suggested a better internalization of drug-loaded NPs compared to free drugs. Most promising results were obtained in CFO and ZFO nanocarriers. Overall, NPs cause dose-dependent cytotoxicity via ROS generation, which causes genotoxicity, p53-mediated cell cycle arrest leading towards apoptosis. Furthermore, $\mathrm{Ki}-67$ expression was highly inhibited $(p<0.005)$ in the presence of CFO+DOX and ZFO+DOX nanocarriers, indicating their anti-proliferative capability in cancer cells. In addition, CFO and ZFO nanocarriers showed significant $(p<0.05)$ inhibition of MDR pump activity in HepG2 and HT144 cells, suggesting their suitability for multidrug resistant cancers. Excellent colloidal stability, magnetic properties (coercivity = 883 and saturation magnetization $=56 \mathrm{emu} / \mathrm{g}$ ), and specificity towards cancer cells support $\mathrm{CFO}$ nanocarriers as promising candidates for targeted cancer therapy domains. However, further investigations regarding pathway analysis, in vivo cytotoxicity, and magnetic-field-assisted drug delivery are needed.

\section{Experimental}

\section{Materials}

Iron nitrate $\left[\mathrm{Fe}\left(\mathrm{NO}_{3}\right)_{3} \cdot 9 \mathrm{H}_{2} \mathrm{O}\right]$ and cobalt nitrate $\left[\mathrm{Co}\left(\mathrm{NO}_{3}\right)_{2} \cdot 6 \mathrm{H}_{2} \mathrm{O}\right](98 \%)$ were purchased from UNI-Chem. Zinc nitrate $\left.\left[\mathrm{Zn}\left(\mathrm{NO}_{3}\right)_{2} \cdot 6 \mathrm{H}_{2} \mathrm{O}\right)\right]$, nickel nitrate $\left[\mathrm{Ni}\left(\mathrm{NO}_{3}\right)_{2} \cdot 6 \mathrm{H}_{2} \mathrm{O}\right]$, chloroform, and oleic acid $\left(\mathrm{C}_{18} \mathrm{H}_{34} \mathrm{O}_{2}\right)$ (>99\%) were purchased from Applichem. Poly(isobutylene-altmaleic anhydride) $(85 \%)$, dodecylamine $(99 \%)$, tetrahydrofuran (THF) (99.9\%), 1-ethyl-3-(3-dimethylaminopropyl)carbodiimide (98\%), doxorubicin (99.9\%), methotrexate (99.9\%), Tris/borate/EDTA buffer (TBE, 98.8\%), Dulbecco's Modified Eagle's Medium (DMEM, 99.9\%), Roswell Park Memorial Institute (RPMI-1640, 99.9\%) medium, GPPS (2 mM L-glutamine, $1 \mathrm{mM}$ Na pyruvate, $100 \mathrm{U} / \mathrm{mL}$ penicillin, $100 \mu \mathrm{g} / \mathrm{mL}$ streptomycin, 98\%), Triton X-100 (lab grade), Trizma base, 
trypsin/EDTA (lab grade), sulforhodamine B (dye content $75 \%$ ), ethidium bromide (lab grade), sodium dodecyl sulfate (SDS, lab grade), 2',7'-dichlorodihydrofluorescein diacetate (>97\%) and 3-(4,5-dimethylthiazol-2-yl)-2,5-diphenyltetrazolium bromide $(97.5 \%$, lab grade), propidium iodide ( $>94 \%)$, acridine orange ( $>98 \%)$, RNAse A $(>60 \%)$ and dimethyl sulfoxide $55 \% \mathrm{w} / \mathrm{v}$ (DMSO) were purchased from Sigma-Aldrich (USA). A DNA ladder (100 bp, research grade) and agarose (low-melting and normal) were purchased from Thermo Fischer Scientific and Hydra Gene Co., Ltd, respectively. Ethanol, trichloroacetic acid (TCA, 99\%), trypan blue, fetal bovine serum (FBS, sterile filtered), orange G, sodium hydroxide $(\mathrm{NaOH}, 99 \%)$, and dibutylphthalate polystyrene xylene (DPX, research grade) mounting medium were purchased from Merck, Germany. Research-grade antigen retrieval solution (K8004), Ki-67 (clone MIB-1), p53 (clone DO-7) mouse monoclonal anti-human antibodies, horseradish peroxidase- (HRP) conjugated secondary antibody (DM822), peroxidase blocker (DM821, lab grade), diaminobenzidine (DAB), chromogen (DM827), and hematoxylin (K8018) ready to use were obtained from Agilent Technologies, Inc. (USA).

\section{Colloidal synthesis of $\mathrm{MFe}_{2} \mathrm{O}_{4}(\mathrm{M}=\mathrm{Fe}, \mathrm{Co}$, $\mathrm{Ni}, \mathrm{Zn}$ ) nanoparticles}

The two-step sonochemical method was used for the synthesis of $\mathrm{MFe}_{2} \mathrm{O}_{4}(\mathrm{M}=\mathrm{Fe}, \mathrm{Co}, \mathrm{Zn}, \mathrm{Ni})$ NPs. The coprecipitation method was used in the first step of the synthesis of $\mathrm{MFe}_{2} \mathrm{O}_{4}$ nanoparticles $(0.2 \mathrm{M})$ by mixing iron nitrate $\left[\mathrm{Fe}\left(\mathrm{NO}_{3}\right)_{3} \cdot 9 \mathrm{H}_{2} \mathrm{O}\right]$ and $(\mathrm{Co} / \mathrm{Zn} / \mathrm{Ni})$ nitrates with a molar ratio of $\mathrm{Fe} / \mathrm{M}(2: 1)$ in $100 \mathrm{~mL}$ of deionized water. The solution was stirred for $15 \mathrm{~min}$, heated at $70{ }^{\circ} \mathrm{C}$, and further stirred for $1 \mathrm{~h}$ after the addition of $\mathrm{NaOH}(3 \mathrm{M})$ which settled down forming precipitates. The precipitates were washed four times and collected with the help of a magnet. The samples were dried in the oven, annealed at $600{ }^{\circ} \mathrm{C}$, and redispersed in oleic acid (1:3) by sonication for $4 \mathrm{~h}$. The resultant precipitates were washed with methanol and resuspended in chloroform [30].

\section{Physical characterizations}

Structural studies were carried out at an XRD D8-Advance Bruker AXS diffractometer with $\mathrm{Cu} \mathrm{K} \alpha$ radiation $(\lambda=1.54 \AA$ ). The Debye-Scherrer formula (Equation 1) was used to calculate the average crystallite size of NPs from the XRD peak of the (311) plane [30]:

$$
D=\frac{K \lambda}{\beta \cos \theta},
$$

where $D$ is the average crystallite size, $K=0.94, \lambda=1.54 \AA$ is the $X$-ray wavelength, $\beta$ represents the full width at half maximum (FWHM), and $\theta$ represents the Bragg's diffraction angle.
The surface morphology and major elemental composition were obtained by high-resolution transmission electron microscopy (JEM 2100F) and energy dispersive spectroscopy (TESCANVEGA3), respectively. The magnetic behavior was determined by using a physical property measurement system (Quantum Design, USA). The colloidal stability and hydrodynamic size of NPs were studied by using a Zetasizer Nano ZS (Malvern Instruments, $69 \mathrm{UK}$ ) and the uniform size distribution by gel electrophoresis (GE BIORAD). Drug attachment and drug release analyses were performed by using UV-vis spectroscopy (Thermo Scientific Evo 220).

\section{Phase transfer, polymer coating, and purification of $\mathrm{MFe}_{2} \mathrm{O}_{4}(\mathrm{M}=\mathrm{Fe}, \mathrm{Co}, \mathrm{Ni}, \mathrm{Zn})$ NPs by gel electrophoresis}

The synthesis and polymer coating of NPs were carried out as previously described $[22,30]$. The nanoparticles $(1 \mathrm{~mL})$ were mixed with $350 \mu \mathrm{L}$ of PMA $(0.8 \mathrm{M})$ and stirred at $60{ }^{\circ} \mathrm{C}$ for $1 \mathrm{~h}$. The samples were slowly dried under vacuum and finally redispersed in SBB pH 9. PMA-coated samples were filtered using a $0.2 \mu \mathrm{m}$ syringe filter and concentrated using centrifugal filters (Amicon Ultra-4). The concentrated samples were purified by using $1 \%$ agarose gel at $100 \mathrm{~V}$ for $90 \mathrm{~min}$. Discrete NP bands on the gel were cut and extracted using a $50 \mathrm{kDa}$ dialysis membrane (Spectrum Laboratories, Inc.) in TBE buffer [66]. Finally, the gel-extracted NPs were concentrated by using centrifugal filters and resuspended in SBB (pH 9.0).

\section{Preparation of drug-loaded nanoparticles}

The purified PMA-coated $\mathrm{MFe}_{2} \mathrm{O}_{4}(\mathrm{M}=\mathrm{Fe}, \mathrm{Co}, \mathrm{Zn}, \mathrm{Ni}) \mathrm{NPs}$ were further modified with DOX and MTX via EDC chemistry. The NPs were incubated with optimized concentrations of EDC and drug (DOX and MTX) for $2 \mathrm{~h}$ at room temperature. The drug attachment to the surface of NP was confirmed by UV-vis spectroscopy [30]. The drugs unbound from the samples were removed by $50 \mathrm{KDa}$ centrifugal filters and their concentration in the waste was confirmed with the help of drug titration curves. Drug encapsulation efficiency (EE) and drug-loading capacity (LC) were determined using the following equations [67]:

$$
\mathrm{EE} \%=\left(\begin{array}{l}
\text { absorbance of drug used }- \\
\text { absorbance of waste }
\end{array}\right) \times 100 .
$$

$$
\mathrm{LC} \%=\left(\frac{\text { entrapped drug }}{\text { nanoparticle weight }}\right) \times 100
$$




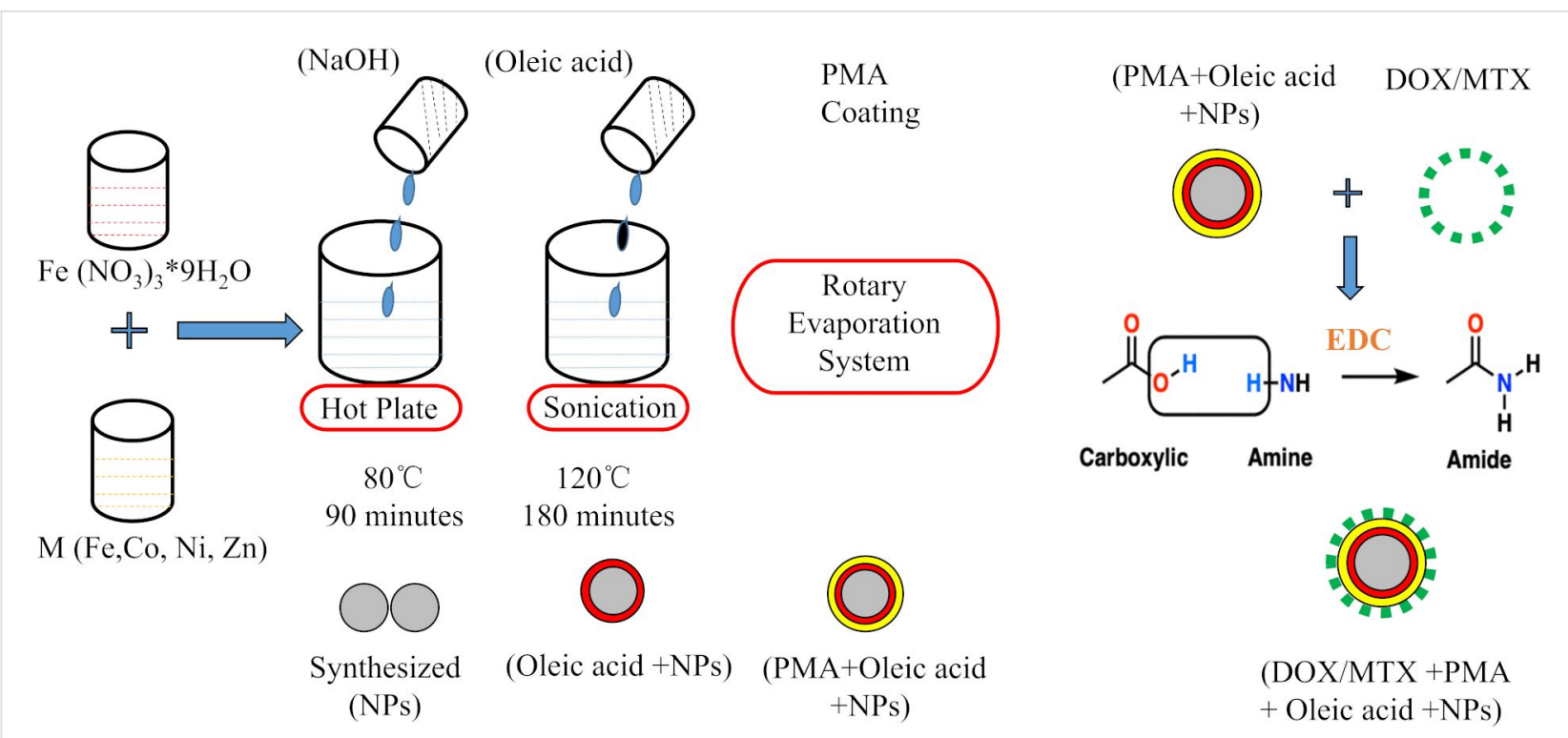

Figure 11: Graphical representation of sonochemical synthesis, PMA-coating, and drug (DOX and MTX) functionalization of MFe $\mathrm{O}_{4}(\mathrm{M}=\mathrm{Fe}, \mathrm{Co}, \mathrm{Zn}$, Ni) NPs.

Figure 11 indicates a graphical representation of the complete synthetic route of drug-functionalized NPs.

\section{$\mathrm{pH}$-dependent drug release kinetics}

Drug release kinetics of DOX- and MTX-loaded $\mathrm{MFe}_{2} \mathrm{O}_{4}(\mathrm{M}=$ $\mathrm{Fe}, \mathrm{Co}, \mathrm{Zn}, \mathrm{Ni}$ ) NPs were studied at different $\mathrm{pH}$ values [68]. The nanoparticles were dispersed in PBS with $\mathrm{pH}$ values ranging from 5.5-7.4 and spectrophotometric data were measured at different time intervals $(0,1,5,10,20,40,60$, and $120 \mathrm{~min}$ ). After every time point, the samples were centrifuged at $10000 \mathrm{rpm}$ for $5 \mathrm{~min}$ and the supernatants were analyzed by spectrophotometry. UV-vis readings were analyzed with the help of DOX and MTX titration curves to estimate the amount of released drugs. The percentage of drug release was calculated by the formula given in Equation 4:

Drug release $\%=\left(\frac{\text { absorbance of supernatant }}{\text { absorbance of drug-loaded NPs }}\right) \times 100$

\section{Cell culture}

The cell lines human malignant melanoma (HT144, ATCC ${ }^{\circledR}$ HTB $-63^{\mathrm{TM}}$ ) and human hepatocellular carcinoma (HepG2, ATCC ${ }^{\circledR} \mathrm{HB}-8065^{\mathrm{TM}}$ ) were used in this study. The cells were grown in DMEM supplemented with 10\% FCS and 1\% GPPS in a humidified incubator $\left(37^{\circ} \mathrm{C}\right)$ with $10 \% \mathrm{CO}_{2}$. The cells were harvested using trypsin/EDTA $(0.5 \mathrm{mM})$ for $1 \mathrm{~min}$ at room temperature.

\section{In vitro cytotoxicity screening of drug-loaded} $\mathrm{MFe}_{2} \mathrm{O}_{4}(\mathrm{M}=\mathrm{Fe}, \mathrm{Co}, \mathrm{Ni}, \mathrm{Zn}) \mathrm{NPs}$

The cytotoxicity screening of colloidal drug-loaded $\mathrm{MFe}_{2} \mathrm{O}_{4}$ ( $\mathrm{M}=\mathrm{Fe}, \mathrm{Co}, \mathrm{Ni}, \mathrm{Zn}$ ) NPs was performed by using the SRB assay in vitro [30]. HepG2 and HT144 cells ( $>90 \%$ viability, $1.5 \times 10^{5}$ cells $/ \mathrm{mL}$ ) were seeded onto 96-well plates $\left(\right.$ Falcon ${ }^{\circledR}$ 96-well, flat-bottom, clear microplate) and treated with $5 \mu \mathrm{g} / \mathrm{mL}$ of drug-loaded NPs for $24 \mathrm{~h}$ at $37^{\circ} \mathrm{C}$, followed by fixation with $50 \%$ trichloroacetic acid (TCA) for $60 \mathrm{~min}$ at $4{ }^{\circ} \mathrm{C}$. The plates were washed thrice with deionized water to remove TCA and then air dried. Afterwards, the SRB dye $(0.05 \%)$ was added at room temperature for $30 \mathrm{~min}$ to stain the cells. The excess dye was washed with $1 \%$ acetic acid $4-5$ times. After the plates were air dried, photographs were taken at a $200 \times$ magnification with an Olympus CK2 light microscope with an attached camera (Optika C-B10 digital camera) and analyzed using the Optika Pro View software (version x86, 3.7.13977.20190224). The experiment was performed twice with triplicates for all samples. The experimental controls included untreated cells, free doxorubicin, free methotrexate, and NPs-PMA.

\section{Determining the $\mathrm{IC}_{50}$ concentration of drug- loaded $\mathrm{MFe}_{2} \mathrm{O}_{4}(\mathrm{M}=\mathrm{Fe}, \mathrm{Co}, \mathrm{Ni}, \mathrm{Zn}) \mathrm{NPs}$}

In order to determine the metabolic activity and half maximal inhibitory concentration $\left(\mathrm{IC}_{50}\right)$ of drug-loaded NPs, the MTT assay was used [66]. HepG2 and HT144 cells (>90\% viability, $1.5 \times 10^{5}$ cells $\left./ \mathrm{mL}\right)$ were exposed to varying concentrations $(1$, $10,25,50$, and $100 \mu \mathrm{g} / \mathrm{mL}$ ) of NPs for $24 \mathrm{~h}$ followed by the addition of MTT $(0.5 \mathrm{mg} / \mathrm{mL})$ and further incubation for $4 \mathrm{~h}$. The MTT reagent was solubilized overnight by using $10 \%$ acidified 
SDS. Control groups included NPs-PMA, NTC, DOX (10 $\mu \mathrm{M})$, and MTX $(10 \mu \mathrm{M})$. Non-cellular controls included replicates of media only and NPs only. The absorbance at $565 \mathrm{~nm}$ was measured using a microplate reader (FLUOstar Omega microplate reader, BMG LABTECH). The percentage values of cellular viability were calculated by using the following formula:

$$
\% \text { viability }=\left(\begin{array}{l}
\text { absorbance of sample- } \\
\frac{\text { absorbance of sample control }}{\text { absorbance of NTC- }} \\
\text { absorbance of media only }
\end{array}\right) \times 100 \text {. }
$$

The $\mathrm{IC}_{50}$ values were calculated by using the following formula:

$$
\mathrm{IC}_{50}=\frac{b-[(b-a)(50 \%-d)]}{(c-d)},
$$

where $a$ and $b$ are the drug concentration values which yield just more than $50 \%$ and just less than $50 \%$ of viable cells, respectively, $c$ is the percentage of viability yielded by the drug concentration value $a$, and $d$ is the percentage of viability yielded by the drug concentration value $b$. The experiment was repeated twice with triplicates for each sample.

\section{Determination of necrotic/apoptotic cells via fluorescence microscopy}

In order to determine the extent of apoptosis and necrosis in treated cells, AOPI staining was used as previously described [30]. Pre-seeded HepG2 and HT144 cells ( $>90 \%$ viability, $1.0 \times 10^{5}$ cells $/ \mathrm{mL}$ ) were treated with drug-loaded NPs (5 and $10 \mu \mathrm{g} / \mathrm{mL}$ ) for $3 \mathrm{~h}$ under appropriate culture conditions. Control groups included NTC, NPs-PMA $(10 \mu \mathrm{g} / \mathrm{mL})$, free DOX and free MTX ( $5 \mu \mathrm{M}$ each). Afterwards, the cells were washed with $1 \times$ PBS and stained with AOPI ( 100 and $32 \mu \mathrm{g} / \mathrm{mL}$ ) for $1 \mathrm{~min}$ at room temperature and visualized under a fluorescence microscope (200×, Nikon, MicroPhot-SA). Green fluorescence indicates viable cells, red fluorescence indicates necrotic cells, whereas yellow to orange fluorescence indicates early and late apoptotic cells, respectively. By using an Optika Pro View (version x86, 3.7.13977.20190224) instrument, live, necrotic, and apoptotic cells were counted, and their percentages were calculated relative to NTC.

\section{Determination of oxidative stress in treated cells}

The cell-permeant $\mathrm{H}_{2}$-DCFDA was used to determine the extent of ROS production in HepG2 and HT144 cells upon treatment with drug-loaded NPs over a period of time (0-45 $\mathrm{min}$ ) [69]. Briefly, cells were seeded onto a 96-well plate at a density of $1.5 \times 10^{5}$ cells $/ \mathrm{mL}$ under appropriate culture conditions. After
$24 \mathrm{~h}$, media were removed, replaced with PBS containing 2\% FCS and $25 \mu \mathrm{M} \mathrm{H}_{2}$-DCFDA, and incubated for $45 \mathrm{~min}$. Cells were treated with NPs at $\mathrm{IC}_{50}$ concentrations and the fluorescence intensity values were recorded using a microplate reader (FLUOstar Omega microplate reader, BMG LABTECH) at various time points and at emission and excitation wavelengths of 355 and $590 \mathrm{~nm}$, respectively (gain $=700$ ). The control groups included free DOX, free MTX $(0.2 \mu \mathrm{M}$ each), and NTC. Non-cellular controls included NPs only and DCF only samples. The experiment was performed in triplicates.

\section{Cell cycle analysis}

The cell cycle analysis was performed by flow cytometry. Pre-seeded HepG 2 and HT144 cells ( $>90 \%$ viability, $1.5 \times 10^{5}$ cells $/ \mathrm{mL}$ ) were treated with $\mathrm{IC}_{50}$ doses of drug-loaded NPs for $24 \mathrm{~h}$. Control groups included NTC and free drugs (DOX and MTX, 0.2 $\mu \mathrm{M}$ each). The cells were harvested, washed with PBS, and fixed in fixative solution containing $70 \%$ ethanol, $10 \%$ PBS, and $20 \%$ deionized water at $4{ }^{\circ} \mathrm{C}$. For flow cytometry, fixed cells were washed with PBS and incubated with a staining solution containing $50 \mu \mathrm{g} / \mathrm{mL}$ of PI and $100 \mu \mathrm{g} / \mathrm{mL}$ of RNase A for $30 \mathrm{~min}$ at room temperature in the dark. The analysis of at least 10000 cells was performed using a flow cytometer (CytoFLEX LX, Beckman Coulter Life Sciences) and the CytExpert software (Version 2.4) [70].

\section{Detection of DNA strand breaks in treated cells: the alkaline comet assay}

A single-cell gel electrophoresis (alkaline comet assay) was performed as described earlier [70]. HepG2 and HT144 cells ( $>90 \%$ viability) were exposed to drug-loaded NPs at $\mathrm{IC}_{50}$ doses for $1 \mathrm{~h}$ under standard culture conditions. Control groups included NTC and free drugs (DOX and MTX, $0.2 \mu \mathrm{M}$ each). The cells were harvested, counted, embedded in $0.7 \%$ lowmelting agarose, and spotted on comet assay slides. After solidification on ice, the slides were immersed into cell lysis buffer (2.5 M NaCl, $100 \mathrm{mM} \mathrm{Na} 2$-EDTA, $10 \mathrm{mM}$ Trizma base $\mathrm{pH} 10$, $1 \%$ sodium sarcosinate, and $1 \%$ Triton-X100) overnight at $4{ }^{\circ} \mathrm{C}$. In the following day, the slides were immersed into a prechilled alkaline solution $\left(0.3 \mathrm{M} \mathrm{NaOH}\right.$ and $1 \mathrm{M} \mathrm{Na}_{2}$-EDTA, $\mathrm{pH} 13$ ) for 20 min to allow for DNA unwinding and electrophoresed for $20 \mathrm{~min}$ at $25 \mathrm{~V}$ and $300 \mathrm{~mA}$. After air drying, staining was performed using PI $(5 \mu \mathrm{g} / \mathrm{mL}$ in PBS $)$ and at least 150 cells were analyzed for each sample using the ImageJ software to calculate median olive tail moment values relative to NTC.

\section{Detection of DNA fragmentation in treated cells}

DNA fragmentation is a hallmark of cellular apoptosis resulting in the formation of small DNA fragments of $180 \mathrm{bp}$ (or 
multiple) which can be visualized on agarose gel [71]. A ladder assay was performed using the DMSO method as described previously [72]. Briefly, HepG2 and HT144 cells ( $>90 \%$ viability, $1.0 \times 10^{5}$ cells $/ \mathrm{mL}$ ) were treated with $\mathrm{IC}_{50}$ doses of drug-loaded NPs for $24 \mathrm{~h}$ at standard culture conditions. The media were removed, cells were washed with PBS and collected via trypsinization. Cellular lysis was performed by adding DMSO $(100 \mu \mathrm{L})$ to the pellets, which were mixed by vortexing. An equal volume of TE buffer (pH 7.4) containing $2 \%$ SDS was added and the samples were vortexed. The samples were then centrifuged at $12000 \mathrm{rpm}$ for $10 \mathrm{~min}$ and the resulting supernatant fractions containing low molecular weight DNA fragments were quantified using the Nanodrop 2000C. Equal amounts of DNA from all samples were electrophoresed on a $2 \%$ agarose gel (containing ethidium bromide at $50 \mu \mathrm{g} / \mathrm{mL}$ ) along with orange $\mathrm{G}$ dye for $2 \mathrm{~h}$ at $50 \mathrm{~V}$. The gel was visualized by using a UV transilluminator and the results were recorded. The control groups included NTC, DOX, and MTX $(30 \mu \mathrm{M})$.

\section{Expression assessment of $\mathrm{Ki}-67$ and p53 cancer biomarkers via immunocytochemistry}

$\mathrm{Ki}-67$ and p53 protein expression was evaluated by ICC [73] (Dako EnVision ${ }^{\mathrm{TM}}$ FLEX detection system). HepG2 and HT144 ( $>90 \%$ viability, $1.5 \times 10^{5}$ cells $/ \mathrm{mL}$ ) cells were cultured on sterile coverslips in 24-well plates. Cells were treated with $\mathrm{IC}_{50}$ doses of drug-loaded NPs for $24 \mathrm{~h}$, followed by fixation with TCA and washing with deionized water. The cells were immersed in an antigen retrieval solution at $95{ }^{\circ} \mathrm{C}$ for $45 \mathrm{~min}$. Endogenous peroxidases were blocked by adding a peroxidase blocker for $10 \mathrm{~min}$. Ki-67 (clone MIB-1, working dilution 1:150) and p53 (clone DO-7, working dilution 1:50) mouse monoclonal antibodies were then added, and the cells were incubated at $4{ }^{\circ} \mathrm{C}$ overnight followed by the addition of HRP-conjugated secondary antibody (rabbit, polyclonal) for 30 min and DAB chromogen for 10 min to obtain the desired dark brown stain with washings in between. The cells were counter stained with hematoxylin, dehydrated, mounted, and observed under a light microscope (Nikon, MicroPhot-SA) at a 200× magnification with an attached camera (Optika C-B10 digital camera) and analyzed by using the Optika Pro View software (version $x 86,3.7 .13977 .20190224)$. The percentage of antibody positive cells was calculated using the following formula:

$\%$ antibody positive cells $=\left(\begin{array}{l}\text { number of } \\ \text { antibody positive cells } \\ \text { total number of cells }\end{array}\right) \times 100 .(7)$

\section{Cytotoxicity assessment of drug-loaded $\mathrm{MFe}_{2} \mathrm{O}_{4}(\mathrm{M}=\mathrm{Fe}, \mathrm{Co}, \mathrm{Ni}, \mathrm{Zn}) \mathrm{NPs}$ in HepG2 and HT144 3D spheroids}

Cancer cells grown in 3D cultures called spheroids, closely resemble their in vivo phenotype. HepG2 and HT144 spheroids were treated with drug-loaded NPs $(5 \mu \mathrm{g} / \mathrm{mL})$ for 14 days to assess their cytotoxicity in $3 \mathrm{D}$ culture models. Control groups included NTC and free drugs (DOX and MTX, $0.2 \mu \mathrm{M}$ each). In brief, HepG 2 and HT144 cells ( $>90 \%$ viability, 5000 cells/well) were seeded onto sterile, agarose-coated $(1.5 \%$ prepared in autoclaved deionized water; $50 \mu \mathrm{L} /$ well) 96 -well plates (Falcon ${ }^{\circledR}$ 96-well, flat-bottom, clear microplate) with $200 \mu \mathrm{L}$ medium/well. The plates were centrifuged at $2500 \mathrm{rpm}$ for 5 min to allow cellular accumulation in the agarose meniscus. The plates were incubated at $37{ }^{\circ} \mathrm{C}$ for three days to allow the formation of closely packed 3D spheroids prior to treatment. The media were changed after every $48 \mathrm{~h}$ [74]. At every time point, photographs were captured at a $100 \times$ magnification using an Olympus CK2 light microscope with an attached camera (Optika C-B10 digital camera) and analyzed using the Optika Pro View software (version x86, 3.7.13977.20190224). The average diameter of the spheroids was determined using the ImageJ software.

At the 14th day of treatment, the spheroids were collected, washed with PBS, and trypsinized for 5 min to obtain a suspension with single cells. The cellular viability was then determined in triplicates using the trypan blue method [75].

\section{Assessment of multidrug resistance pump activity in treated HepG2 and HT144 cells}

HepG2 and HT144 exhibit intrinsic expression of ATP-binding cassette $(\mathrm{ABC})$ transporters responsible for inducing multidrug resistance in response to chemotherapy $[76,77]$.

Here, a fluorometric MDR assay kit (ab 112142, Abcam, Cambridge, MA, USA) was used to determine MDR1 and MRP1 activity in HepG2 and HT144 cells using the protocol suggested by the manufacturer [78]. In brief, cells ( $>90 \%$ viability, $1.5 \times 10^{5}$ cells $/ \mathrm{mL}$ ) were treated with drug-loaded NPs at $\mathrm{IC}_{50}$ doses for $24 \mathrm{~h}$. Free drug controls (DOX and MTX, $0.2 \mu \mathrm{M}$ each) and NTC were included as controls. Cyclosporin A $(10 \mu \mathrm{M})$ was included as a positive control. After treatment, the plates were incubated at room temperature with a dye loading solution $(100 \mu \mathrm{L} /$ well $)$ for $3 \mathrm{~h}$ in the dark. Fluorescence intensity relative to NTC was determined after subtracting the drug only background at $485 / 530 \mathrm{~nm}$ using a plate reader (FLUOstar Omega microplate reader, BMG LABTECH). The higher the cellular fluorescence, the higher the MDR pump inhibition. The experiment was performed in triplicates for all samples. 
$\mathrm{IC}_{50}$ of drug-loaded $\mathrm{MFe}_{2} \mathrm{O}_{4}(\mathrm{M}=\mathrm{Fe}, \mathrm{Co}, \mathrm{Ni}$, $\mathrm{Zn)}$ NPs in normal cells: biocompatibility

\section{assessment}

The cytotoxicity of drug-loaded NPs was evaluated in fresh lymphocytes in vitro. Fresh peripheral blood $(5 \mathrm{~mL})$ was collected from healthy individuals in EDTA vacutainers under informed consent. The blood was diluted (1:3) with RBCs lysis buffer $\left(155 \mathrm{mM} \mathrm{NH}_{4} \mathrm{Cl}, 0.1 \mathrm{mM}\right.$ EDTA, and $10 \mathrm{mM} \mathrm{KHCO}_{3}$; $\mathrm{pH}$ 7.2) and incubated at room temperature for $5 \mathrm{~min}$ with mixing in between, followed by centrifugation at $2000 \mathrm{~g}$ for $5 \mathrm{~min}$. The process was repeated 5 times to obtain a clear pellet of lymphocytes [79]. The lymphocytes were resuspended in RPMI-1640 medium containing 10\% FCS and 1\% GPPS. Cell viability was assessed via the trypan blue method [75].

$\mathrm{IC}_{50}$ concentrations of drug-loaded NPs were calculated by performing an MTT assay as described previously.

\section{Funding}

This project was funded by the Higher Education Commission (HEC) Pakistan, grant no. 9944/Federal/NRPU/R\&D/HEC/ 2017. Sadaf Mushtaq was also supported by HEC indigenous scholarship for PhD (Phase 2, Batch 3), P. No. 315-4657-2BS3052.

\section{ORCID ${ }^{\circledR}$ iDs}

Sadaf Mushtaq - https://orcid.org/0000-0002-9990-2164 Anwar UI-Hamid - https://orcid.org/0000-0002-0259-301X Bilal Haider Abbasi - https://orcid.org/0000-0002-6529-2134 Zulqurnain Ali - https://orcid.org/0000-0001-5912-5957 Rashda Abbasi - https://orcid.org/0000-0002-0268-0359

\section{Preprint}

A non-peer-reviewed version of this article has been previously published as a preprint: https://doi.org/10.3762/bxiv.2021.56.v1

\section{References}

1. Meidanchi, A.; Ansari, H. J. Cluster Sci. 2021, 32, 657-663. doi:10.1007/s10876-020-01832-5

2. Kanagesan, S.; Hashim, M.; Tamilselvan, S.; Alitheen, N. B.; Ismail, I.; Bahmanrokh, G. J. Nanomater. 2013, 2013, 865024. doi:10.1155/2013/865024

3. Huang, J.; Li, H.; Chen, W.; Lv, G.-H.; Wang, X.-Q.; Zhang, G.-P.; Ostrikov, K.; Wang, P.-Y.; Yang, S.-Z. Appl. Phys. Lett. 2011, 99, 253701. doi:10.1063/1.3666819

4. Raj, S.; Khurana, S.; Choudhari, R.; Kesari, K. K.; Kamal, M. A.; Garg, N.; Ruokolainen, J.; Das, B. C.; Kumar, D. Semin. Cancer Biol. 2021, 69, 166-177. doi:10.1016/j.semcancer.2019.11.002

5. Onoue, S.; Yamada, S.; Chan, H.-K. Int. J. Nanomed. 2014, 9 , 1025-1037. doi:10.2147/ijn.s38378

6. Yin Win, K.; Feng, S.-S. Biomaterials 2005, 26, 2713-2722. doi:10.1016/j.biomaterials.2004.07.050
7. Kalyane, D.; Raval, N.; Maheshwari, R.; Tambe, V.; Kalia, K.; Tekade, R. K. Mater. Sci. Eng., C 2019, 98, 1252-1276. doi:10.1016/j.msec.2019.01.066

8. Issa, B.; Obaidat, I. M.; Albiss, B. A.; Haik, Y. Int. J. Mol. Sci. 2013, 14, 21266-21305. doi:10.3390/ijms141121266

9. Wu, Y.; Yang, X.; Yi, X.; Liu, Y.; Chen, Y.; Liu, G.; Li, R.-W. HSOA J. Nanotechnol.: Nanomed. Nanobiotechnol. 2015, 2, 1-7. doi:10.24966/ntmb-2044/100003

10. Kalubowilage, M.; Janik, K.; Bossmann, S. H. Appl. Sci. 2019, 9, 2927. doi:10.3390/app9142927

11. Popescu, R. C.; Andronescu, E.; Vasile, B. S. Nanomaterials 2019, 9, 1791. doi:10.3390/nano9121791

12. Srinivasan, S. Y.; Paknikar, K. M.; Bodas, D.; Gajbhiye, V. Nanomedicine (London, U. K.) 2018, 13, 1221-1238. doi:10.2217/nnm-2017-0379

13. Sharifi, I.; Shokrollahi, H.; Amiri, S. J. Magn. Magn. Mater. 2012, 324, 903-915. doi:10.1016/j.jmmm.2011.10.017

14. Szotek, Z.; Temmerman, W. M.; Ködderitzsch, D.; Svane, A.; Petit, L.; Winter, H. Phys. Rev. B 2006, 74, 174431. doi:10.1103/physrevb.74.174431

15. Franco, A., Jr.; e Silva, F. C. Appl. Phys. Lett. 2010, 96, 172505. doi:10.1063/1.3422478

16. Gonzalez-Fernandez, M. A.; Torres, T. E.; Andrés-Vergés, M.; Costo, R.; de la Presa, P.; Serna, C. J.; Morales, M. P.; Marquina, C.; Ibarra, M. R.; Goya, G. F. J. Solid State Chem. 2009, 182, 2779-2784. doi:10.1016/j.jssc.2009.07.047

17. Sun, S.; Zeng, H.; Robinson, D. B.; Raoux, S.; Rice, P. M.; Wang, S. X.; Li, G. J. Am. Chem. Soc. 2004, 126, 273-279. doi:10.1021/ja0380852

18. Sanità, G.; Carrese, B.; Lamberti, A. Front. Mol. Biosci. 2020, 7 , 587012. doi:10.3389/fmolb.2020.587012

19. Mushtaq, M. W.; Kanwal, F.; Islam, A.; Ahmed, K.; Haq, Z.-u.; Jamil, T.; Imran, M.; Abbas, S. M.; Huang, Q. Trop. J. Pharm. Res. 2017, 16, 1663-1674. doi:10.4314/tjpr.v16i7.27

20. Burke, N. A. D.; Stöver, H. D. H.; Dawson, F. P. Chem. Mater. 2002, 14, 4752-4761. doi:10.1021/cm020126q

21. Victory, M.; Pant, R. P.; Phanjoubam, S. Mater. Chem. Phys. 2020, 240, 122210. doi:10.1016/j.matchemphys.2019.122210

22. Lin, C.-A. J.; Sperling, R. A.; Li, J. K.; Yang, T.-Y.; Li, P.-Y.; Zanella, M.; Chang, W. H.; Parak, W. J. Small 2008, 4, 334-341. doi:10.1002/smll.200700654

23. Peng, E.; Choo, E. S. G.; Sheng, Y.; Xue, J. M. New J. Chem. 2013, 37, 2051-2060. doi:10.1039/c3nj41162a

24. Hochepied, J. F.; Pileni, M. P. J. Magn. Magn. Mater. 2001, 231, 45-52. doi:10.1016/s0304-8853(01)00044-0

25. Gambardella, P.; Rusponi, S.; Veronese, M.; Dhesi, S. S.; Grazioli, C.; Dallmeyer, A.; Cabria, I.; Zeller, R.; Dederichs, P. H.; Kern, K.; Carbone, C.; Brune, H. Science 2003, 300, 1130-1133. doi:10.1126/science.1082857

26. Rondinone, A. J.; Samia, A. C. S.; Zhang, Z. J. Appl. Phys. Lett. 2000, 76, 3624-3626. doi:10.1063/1.126727

27. Jacob, J.; Khadar, M. A. J. Appl. Phys. 2010, 107, 114310. doi:10.1063/1.3429202

28. Reyes-Ortega, F.; Delgado, Á. V.; Schneider, E. K.; Checa Fernández, B.; Iglesias, G. R. Polymers (Basel, Switz.) 2018, 10, 10. doi:10.3390/polym10010010

29. Kim, J.-K.; Lawler, D. F. Bull. Korean Chem. Soc. 2005, 26 , 1083-1089. doi:10.5012/bkcs.2005.26.7.1083 
30. Shahzad, K.; Mushtaq, S.; Rizwan, M.; Khalid, W.; Atif, M.; Din, F. U.; Ahmad, N.; Abbasi, R.; Ali, Z. Mater. Sci. Eng., C 2021, 119, 111444. doi:10.1016/j.msec.2020.111444

31. Behzadi, S.; Serpooshan, V.; Tao, W.; Hamaly, M. A.; Alkawareek, M. Y.; Dreaden, E. C.; Brown, D.; Alkilany, A. M.; Farokhzad, O. C.; Mahmoudi, M. Chem. Soc. Rev. 2017, 46, 4218-4244. doi:10.1039/c6cs00636a

32. Jain, S.; Bharti, S.; Kaur Bhullar, G.; Tripathi, S. K. Mater. Chem. Phys. 2020, 240, 122162. doi:10.1016/j.matchemphys.2019.122162

33. Han, U.; Seo, Y.; Hong, J. Sci. Rep. 2016, 6, 24158. doi:10.1038/srep24158

34. Cha, E.-J.; Kim, J. E.; Ahn, C.-H. Macromol. Res. 2010, 18, 686-689. doi:10.1007/s13233-010-0708-5

35. Boedtkjer, E.; Pedersen, S. F. Annu. Rev. Physiol. 2020, 82, 103-126. doi:10.1146/annurev-physiol-021119-034627

36. Prabaharan, M.; Grailer, J. J.; Pilla, S.; Steeber, D. A.; Gong, S. Biomaterials 2009, 30, 6065-6075. doi:10.1016/j.biomaterials.2009.07.048

37. Kang, H.; Rho, S.; Stiles, W. R.; Hu, S.; Baek, Y.; Hwang, D. W.; Kashiwagi, S.; Kim, M. S.; Choi, H. S. Adv. Healthcare Mater. 2020, 9 , 1901223. doi:10.1002/adhm.201901223

38. Marisca, O. T.; Kantner, K.; Pfeiffer, C.; Zhang, Q.; Pelaz, B.; Leopold, N.; Parak, W. J.; Rejman, J. Nanomaterials 2015, 5, 1418-1430. doi:10.3390/nano5031418

39. Alhadlaq, H. A.; Akhtar, M. J.; Ahamed, M. Cell Biosci. 2015, 5, 55. doi:10.1186/s13578-015-0046-6

40. Sukhanova, A.; Bozrova, S.; Sokolov, P.; Berestovoy, M.; Karaulov, A.; Nabiev, I. Nanoscale Res. Lett. 2018, 13, 44. doi:10.1186/s11671-018-2457-x

41. Alhadlaq, H. A.; Akhtar, M. J.; Ahamed, M. Cell Biosci. 2015, 5, 55. doi:10.1186/s13578-015-0046-6

42. Ahamed, M.; Alhadlaq, H. A. OncoTargets Ther. 2014, 7, 269-280. doi:10.2147/ott.s58044

43. Alarifi, S.; Ali, D.; Alkahtani, S.; Alhader, M. S. Biol. Trace Elem. Res. 2014, 159, 416-424. doi:10.1007/s12011-014-9972-0

44. Joris, F.; Valdepérez, D.; Pelaz, B.; Soenen, S. J.; Manshian, B. B.; Parak, W. J.; De Smedt, S. C.; Raemdonck, K. J. Nanobiotechnol. 2016, 14, 69. doi:10.1186/s12951-016-0220-y

45. Sabella, S.; Carney, R. P.; Brunetti, V.; Malvindi, M. A.; Al-Juffali, N.; Vecchio, G.; Janes, S. M.; Bakr, O. M.; Cingolani, R.; Stellacci, F.; Pompa, P. P. Nanoscale 2014, 6, 7052-7061. doi:10.1039/c4nr01234h

46. Zhang, H.; Wang, X.; Wang, M.; Li, L.; Chang, C. H.; Ji, Z.; Xia, T.; Nel, A. E. Small 2015, 11, 3797-3805. doi:10.1002/smll.201500251

47. Yao, Y.; Zang, Y.; Qu, J.; Tang, M.; Zhang, T. Int. J. Nanomed. 2019, 14, 8787-8804. doi:10.2147/ijn.s212907

48. Carrasco-Torres, G.; Baltiérrez-Hoyos, R.; Andrade-Jorge, E.; Villa-Treviño, S.; Trujillo-Ferrara, J. G.; Vásquez-Garzón, V. R. Oxid. Med. Cell. Longevity 2017, 2017, 2734976. doi:10.1155/2017/2734976

49. Lee, T.; Lau, T.; Ng, I. Cancer Chemother. Pharmacol. 2002, 49, 78-86. doi:10.1007/s00280-001-0376-4

50. Tsurusawa, M.; Niwa, M.; Katano, N.; Fujimoto, T. Jpn. J. Cancer Res. 1990, 81, 85-90. doi:10.1111/j.1349-7006.1990.tb02511.x

51. Catalán, J.; Suhonen, S.; Huk, A.; Dusinska, M. Analysis of nanoparticle-induced DNA damage by the comet assay. In Genotoxicity and DNA repair; Sierra, L. M.; Gaivão, I., Eds.; Springer New York: New York, NY, U.S.A., 2014; pp 241-268. doi:10.1007/978-1-4939-1068-7_14

52. Magaye, R.; Zhao, J.; Bowman, L.; Ding, M. Exp. Ther. Med. 2012, 4, 551-561. doi:10.3892/etm.2012.656
53. Kaygisiz, Ş. Y.; Ciğerci, İ. H. Toxicol. Ind. Health 2017, 33, 802-809. doi:10.1177/0748233717722907

54. Perde-Schrepler, M.; Florea, A.; Brie, I.; Virag, P.; Fischer-Fodor, E.; Vâlcan, A.; Gurzău, E.; Lisencu, C.; Maniu, A. J. Nanomater. 2019, 2019, 6090259. doi:10.1155/2019/6090259

55. Ahamed, M.; Karns, M.; Goodson, M.; Rowe, J.; Hussain, S. M.; Schlager, J. J.; Hong, Y. Toxicol. Appl. Pharmacol. 2008, 233, 404-410. doi:10.1016/j.taap.2008.09.015

56. Hong, S. C.; Lee, J. H.; Lee, J.; Kim, H. Y.; Park, J. Y.; Cho, J.; Lee, J.; Han, D.-W. Int. J. Nanomed. 2011, 6, 3219-3231. doi:10.2147/jn.s26355

57. Pflaum, J.; Schlosser, S.; Müller, M. Front. Oncol. 2014, 4, 285. doi:10.3389/fonc.2014.00285

58. Chen, J. Cold Spring Harbor Perspect. Med. 2016, 6, a026104. doi:10.1101/cshperspect.a026104

59. Ragab, H. M.; Samy, N.; Afify, M.; Abd El Maksoud, N.; Shaaban, H. M. J. Genet. Eng. Biotechnol. 2018, 16, 479-484. doi:10.1016/j.jgeb.2018.03.002

60. Urruticoechea, A.; Smith, I. E.; Dowsett, M. J. Clin. Oncol. 2005, 23, 7212-7220. doi:10.1200/jco.2005.07.501

61. Surova, O.; Zhivotovsky, B. Oncogene 2013, 32, 3789-3797. doi:10.1038/onc.2012.556

62. Daunys, S.; Janonienè, A.; Januškevičienè, I.; Paškevičiūtè, M.; Petrikaitè, V. 3D Tumor Spheroid Models for In Vitro Therapeutic Screening of Nanoparticles. In Bio-Nanomedicine for Cancer Therapy; Fontana, F.; Santos, H. A., Eds.; Springer: Cham, Switzerland, 2021; pp 243-270. doi:10.1007/978-3-030-58174-9_11

63. de León Valeria, P.; Barrera-Rodríguez, R. Cancer Cell Int. 2005, 5, 20 doi:10.1186/1475-2867-5-20

64. Zöchbauer-Müller, S.; Filipits, M.; Rudas, M.; Brunner, R.; Krajnik, G.; Suchomel, R.; Schmid, K.; Pirker, R. Anticancer Res. 2001, 21, 119-124.

65. Asati, A.; Santra, S.; Kaittanis, C.; Perez, J. M. ACS Nano 2010, 4, 5321-5331. doi:10.1021/nn100816s

66. Ali, Z.; Abbasi, R.; Khan, A. J.; Arshad, J.; Atif, M.; Ahmad, N.; Khalid, W. Mater. Res. Express 2018, 5, 056103. doi:10.1088/2053-1591/aac0c3

67. Shi, Y.; Wan, A.; Shi, Y.; Zhang, Y.; Chen, Y. BioMed Res. Int. 2014, 2014, 613619. doi:10.1155/2014/613619

68. Jia, H.; Kerr, L. L. J. Appl. Polym. Sci. 2015, 132, 41570. doi:10.1002/app.41570

69. Wang, X.; Roper, M. G. Anal. Methods 2014, 6, 3019-3024. doi:10.1039/c4ay00288a

70. Abbasi, R.; Efferth, T.; Kuhmann, C.; Opatz, T.; Hao, X.; Popanda, O.; Schmezer, P. Toxicol. Appl. Pharmacol. 2012, 259, 302-310. doi:10.1016/j.taap.2012.01.006

71. Peitsh, M. C.; Muüller, C.; Tschopp, J. Nucleic Acids Res. 1993, 21 , 4206-4209. doi:10.1093/nar/21.18.4206

72. Suman, S.; Pandey, A.; Chandna, S. Cytotechnology 2012, 64, 9-14. doi:10.1007/s10616-011-9395-0

73. Wan, R.; Mo, Y.; Zhang, Z.; Jiang, M.; Tang, S.; Zhang, Q. Part. Fibre Toxicol. 2017, 14, 38. doi:10.1186/s12989-017-0219-z

74. Nguyen, K.; Nuß, B.; Mühlberger, M.; Unterweger, H.; Friedrich, R. P.; Alexiou, C.; Janko, C. Nanomaterials 2020, 10, 1577. doi:10.3390/nano10081577

75. Strober, W. Curr. Protoc. Immunol. 1997, 21, A.3B.1-A.3B.2. doi:10.1002/0471142735.ima03bs21

76. Roelofsen, H.; Vos, T. A.; Schippers, I. J.; Kuipers, F.; Koning, H.; Moshage, H.; Jansen, P.; Muller, M. Gastroenterology 1997, 112, 511-521. doi:10.1053/gast.1997.v112.pm9024305 
77. Berger, W.; Hauptmann, E.; Elbling, L.; Vetterlein, M.; Kokoschka, E. M.; Micksche, M. Int. J. Cancer 1997, 71, 108-115. doi:10.1002/(sici)1097-0215(19970328)71:1<108::aid-ijc18>3.0.co;2-e

78. Wang, X.; Li, Y.; Qian, Y.; Cao, Y.; Shriwas, P.; Zhang, H.; Chen, X. Oncotarget 2017, 8, 87860-87877. doi:10.18632/oncotarget.21231

79. Dagur, P. K.; McCoy, J. P., Jr. Curr. Protoc. Cytom. 2015, 73, 5.1.1-5.1.16. doi:10.1002/0471142956.cy0501s73

\section{License and Terms}

This is an open access article licensed under the terms of the Beilstein-Institut Open Access License Agreement (https://www.beilstein-journals.org/bjnano/terms), which is identical to the Creative Commons Attribution 4.0 International License

(https://creativecommons.org/licenses/by/4.0). The reuse of material under this license requires that the author(s), source and license are credited. Third-party material in this article could be subject to other licenses (typically indicated in the credit line), and in this case, users are required to obtain permission from the license holder to reuse the material.

The definitive version of this article is the electronic one which can be found at: https://doi.org/10.3762/bjnano.12.99 